Natalie Gutgesell

\title{
THE BALTIC PORTRAIT AND STILL LIFE PAINTER ALEXANDRA VON BERCKHOLTZ (1821-1899)
}

Alexandra von Berckholtz was one of the most renowned female painters of the 19th century. In the 1860s alone, she created over 200 portraits of aristocrats and society personalities in Munich. She had an established network of numerous members of European royal houses, noblewomen and -men, actors, singers, pioneers of science, and artists. She showed commitment to the social issues of her time and supported several charitable organizations, such as the children's orphanage and the Women's Association (Frauenverein) in Karlsruhe, and the Artists' Benefit Society (Künstler-Unterstützungsverein) in Munich.

Her work and life, however, have been absent from the art-historical memory. Most of her works are in private collections today. Only twelve of her paintings found their way into museums and public collections. The Ritterhaus Museum in Offenburg houses four canvases, Augustinermuseum in Freiburg two, the Town Hall of Ortenberg/Baden two, the City Gallery in Karlsruhe two, the Abbey Beuron one and the Museo Poschiavino Palazzo Mengotti Poschiavo in Switzerland one. Through an international research project beginning in 2014 it was possible to rediscover 113 of her works worldwide and to establish a catalogue raisonné of 144 records. The results were published in a 
monograph in May 2017. ${ }^{1}$ Since the publication date, 50 new works and one sketchbook have additionally been discovered. Among them are the portrait of Carl Otto von Loewenstern, and a still life in the Art Museum of Estonia in Tallinn. ${ }^{2}$ The description of the two works will be taken up again later in the text.

Alexandra von Berckholtz was born on 26 August 1821 in Riga as the youngest of eight children of the merchant Gabriel Leonhard von Berckholtz (1781-1863) and Barbara Schroeder (1785-1859). Her grandfather Jacob Johann Berckholtz (1750-1812) was awarded the title of nobility in 1793 by Franz II (1768-1835), the last emperor of the Holy Roman Empire of the German nation and the first Austrian Emperor. In 1825, Gabriel Leonhard emigrated with his wife, his daughters Anna Natalie (1808-1836), Sophie (1810-1878), Olga (1811-1858), Elisabeth (1814-1892), Alexandra, his son Jacob Johann (1815-1887), and the family's servant Johann Heinrich Neese (1795-1885). ${ }^{3}$ Eight years of travelling throughout Europe followed, of which nothing has been known so far. It can be assumed that the Berckholtz family stayed for a time in Paris, for Gabriel Leonhard's brother, Jacob Johann von Berckholtz (1783-1856), had already left Livonia in 1819 and emigrated to Paris, where he lived at Boulevard Poissonnière 24 and rue de la Chaussée d'Antin 2 as a privateer. ${ }^{4}$

The next historical trace is the purchase of a house in Karlstrasse 26 in Karlsruhe by Gabriel Leonhard von Berckholtz in 1833. In this palace the family established a salon which was frequented by several important people of the Karlsruhe society, above all the Grand Duchess Sophie (1801-1865) and her daughter Alexandrine, the later Duchess of Saxe-Coburg and Gotha (1820-1904). Other personalities included the actress Amalie Haizinger (1800-1884), her husband, the singer Anton Haizinger (1796-1869), and the pioneer in chemistry Karl Weltzien (1813-1870). Among the many artists was the historical

1 Natalie Gutgesell, Alexandra von Berckholtz. Malerin und Mäzenin im 19. Jahrhunder (Halle: Mitteldeutscher Verlag, 2017). The monograph presents the results of an internationa research project started in 2014 on the reconstruction of Alexandra von Berckholtz' biography
and discovery of her works worldwide. The present article adds new and recently discovered information to the book.

2 The author would particularly like to thank Ms. Kersti Kuldna-Türkson, Head of the Collections Management, for her support in this context.

3 Two other children died at an early age: Barbara (1817-1820) and Gabriel Leonhard (1819-1821).

4 Bulletin des lois de la république française, Tome neuvième, 1829 (Paris), 9. painter Karl Friedrich Lessing (1808-1880), whose daughter Bertha (1844-1914) was portrayed twice by Alexandra - in 1858 and $1863 .{ }^{5}$ She also created portraits of painter of battle scenes Feodor Dietz (1813-1870) in $1863,{ }^{6}$ landscapist Johann Wilhelm Schirmer (1807-1863) in $1863,{ }^{7}$ and painter Adolph Schroedter (1805-1875), whom she drew in her sketchbook on 12 September 1862 (Fig. 1).

In the 1830s and 1840s Alexandra von Berckholtz frequented the Grand Duke's gallery of paintings in Karlsruhe. Her later work from the 1890s includes copies of still lifes exhibited in the Karlsruhe gallery, such as Jan Davidsz. de Heem's Festoon of Flowers and Fruits. ${ }^{8}$

Amalie von Brueck (Fig. 2) in an oval frame presents a characteristic example of the pictorial style and visual construction of her nobility portraits. The image is signed and dated on the bottom right with "A v. Berckholtz 1846". It was auctioned on 29 June 2017 at Dorotheum Vienna and is currently part of a private collection..$^{9}$ The depicted woman, with brown pinned-up hair and a braided plait at the back of her head arranged in a ring, is presented in a half-length portrait and in a three-quarter profile to the right. She is wearing a light blue dress with a white lace collar and a pink bow tied to her neck. Amalie was born in 1825/27 in Offenburg as the eldest of three daughters of Wilhelm von Rottenhoff (born in 1785) and Elisabeth Stuber (born in 1790), and died in 1878/79 in Munich. She married Ludwig von Brueck (1812-1888), with whom she had three daughters and three sons. ${ }^{10}$ Alexandra von Berckholtz also painted another friendship portrait of another von Brueck family member, namely of Josefine von Brueck in $1868,{ }^{11}$ of which a pencil sketch in a similar framing to Amalie's image has remained. The whereabouts of the oil painting are unknown today.

5 Gutgesell, Alexandra von Berckholtz. Malerin und Mäzenin im 19. Jahrhundert, 220-221, No. 11

6 Ibidem, 222-223, No. 12.

Ibidem, 256-257, No. 29.

8 Oil on canvas, $58.8 \times 80 \mathrm{~cm}$, Staatliche Kunsthalle Karlsruhe Inv.-Nr. 361; Gutgesell, Alexandra von Berckholtz. Malerin und Mäzenin im 19. Jahrhundert, 403-405, №. 102 9 Ölgemälde und Aquarelle des 19. Jahrhunderts. Auktion am 29. Juni 2017 (Wien: Dorotheum,
2017), No. 107.

10 Regarding her birth and death, different years were mentioned in: www.myheritage.de (1825-1878) and www.gedbas.genealogy.net (1827-1879) (accessed 29.10.2018).

11 Julius Meyer, Allgemeines Künstler-Lexicon, Vol. 3 (Leipzig: Engelmann, 1885), 586-587; Natalie Gutgesell, Alexandra von Berckholtz. Malerin und Mäzenin im 19. Jahrhundert, 138-139. 

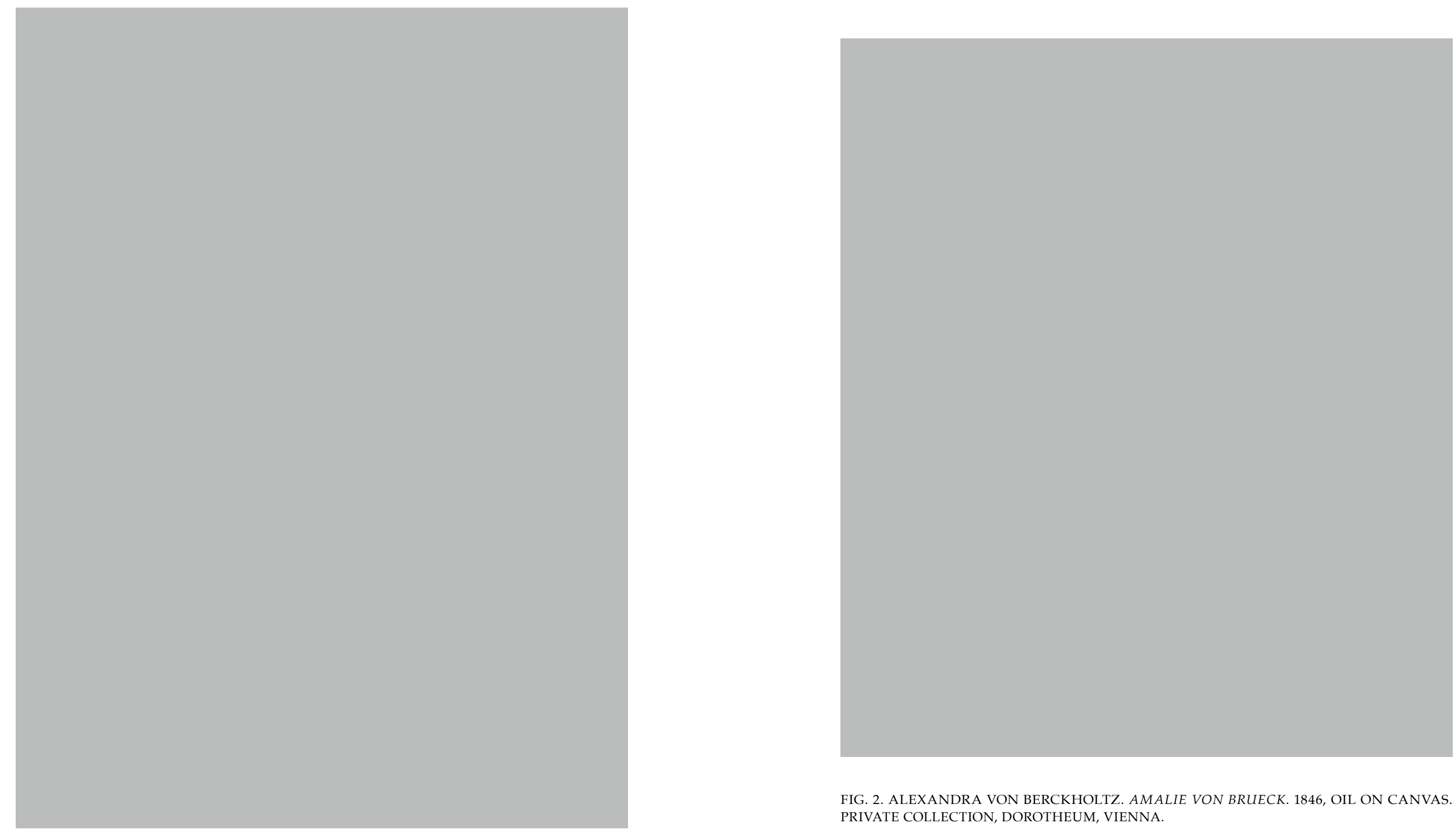

FIG. 2. ALEXANDRA VON BERCKHOLTZ. AMALIE VON BRUECK. 1846, OIL ON CANVAS. PRIVATE COLLECTION, DOROTHEUM, VIENNA.

FIG. 1. ALEXANDRA VON BERCKHOLTZ. ADOLPH SCHROEDTER. 1862, PENCIL ON PAPER $22.3 \times 17$ CM. PRIVATE COLLECTION, FRANKFURT/MAIN. 


\section{EARLY STUDIES WITH LOUIS WAGNER AND FIRST DRAWINGS RECENTLY DISCOVERED}

From 1841 onward, Alexandra von Berckholtz studied at the studio of Louis Wagner (around 1780-after 1853) in Karlsruhe. ${ }^{12}$ Wagner himself was educated in portraiture in Paris, Mannheim, and Munich, where he enrolled in the Royal Academy of Arts on 20 May $1829 .{ }^{13}$ In Munich he took part in the annual academic exhibition of 1829 with two drawings of nude studies. ${ }^{14}$ Wagner must have left the academy before 1832, because that year he was not among the participants of the exhibition. ${ }^{15}$

Alexandra's portrait of Amalie von Brueck clearly reflects Wagner's concentration on an almost photorealistic representation, his brushstroke and his framing - compared to his watercolour with white heightening of a lady with brown curls in a blue dress seated in a chair in front of a curtain (Fig. 3). It is signed and dated on lower left - "L. Wagner. 1842." - and it is sheet number 37 of the album presented to Princess Alexandrine of Baden as a gift on her wedding to Duke Ernest II of Saxe-Coburg and Gotha (1818-1893) in 1842 by 52 artists from Baden. ${ }^{16}$ It can be assumed that the unknown lady resembling Alexandra's portrait of Amalie von Brueck could have been a friend of Duchess Alexandrine. Maybe the woman in question is Amalie's sister Mathilde von Rottenhoff (1829-1911)?

Except for this single coloured sheet, only lithographs of Wagner's drawings - mainly portraits - have remained, e.g. in the city

12 Gitta Ho, "Berckholtz (Berkholz), Alexandra von", Pariser Lehrjahre. Ein Lexikon zur Ausbildung deutscher Maler in der französischen Hauptstadt. Band II: 1844-1870, ed. by France Nerlich, Bénédicte Savoy (Berlin; Boston: De Gruyter, 2015), 9-11; Gutgesell, Alexandra von Berckholtz. Malerin und Mäzenin im 19. Jahrhundert, 22.

13 Ludwig Wagner, Matrikelbuch 1809-1841, No. 01512, matrikel.adbk.de/matrikel/mb 18091841/jahr_1829/matrikel-01512 (accessed 29.10.2018).

14 Verzeichniss der Kunstausstellung der Königlich Bayerischen Akademie der Bildenden Künste am 12. Oktober 1829, ed. by Königlich Bayerische Akademie der Bildenden Künste (München: E. A. Fleischmann, 1829), 44, No. 559, 560

15 Verzeichniss der Kunstausstellung der Königlich Bayerischen Akademie der Bildenden Künste am 12. Oktober 1832, ed. by Königlich Bayerische Akademie der Bildenden Künste (München: E. A. Fleischmann, 1832)

16 Natalie Gutgesell, "Alexandra von Berckholtz, eine europäische Malerin aus der Ortenau", Die Ortenau. Zeitschrift des Historischen Vereins für Mittelbaden, 97 (2017), 35-66, esp. 43, 62, Natalie Gutgesell, "Die Werke der Malein Mate Ellenieder in der Sammlung der Herzogin), Alexandrine von Sachsen-Coburg und Gotha", Jahrbuch der Coburger Landesstiftung, 61 (2017), $61,169-196$, esp. $182-183$.

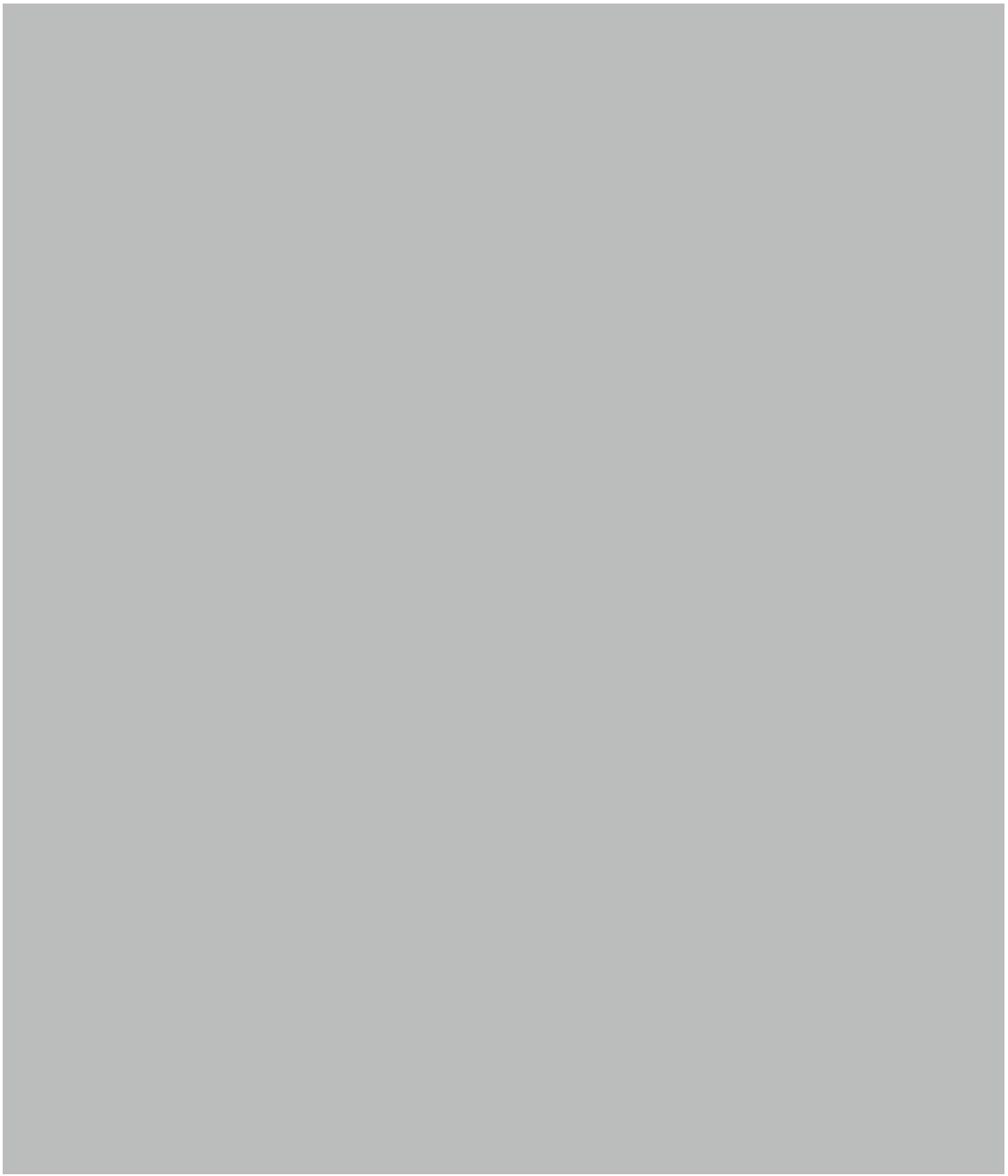

FIG. 3. LOUIS WAGNER. PORTRAIT OF AN UNKNOWN LADY. 1842, WATERCOLOUR. ART COLLECTIONS OF THE VESTE COBURG, INV.-NO. Z.6676. ART COLLECTIONS OF THE VESTE COBURG.

archives of Offenburg and Karlsruhe. ${ }^{17}$ The later court painter and photographer of Baden also drew Alexandra von Berckholtz in front

17 E.g. Portrait Baron Jules Goeler von Ravensburg, $26 \times 17 \mathrm{~cm}$, Berckholtz-Album, City Archives of Offenburg Inv.-No. 26/21/44-45. Gutgesell, Alexandra von Berckholtz. Malerin und
Mäzenin im 19. Jahrhundert, 163-165. 


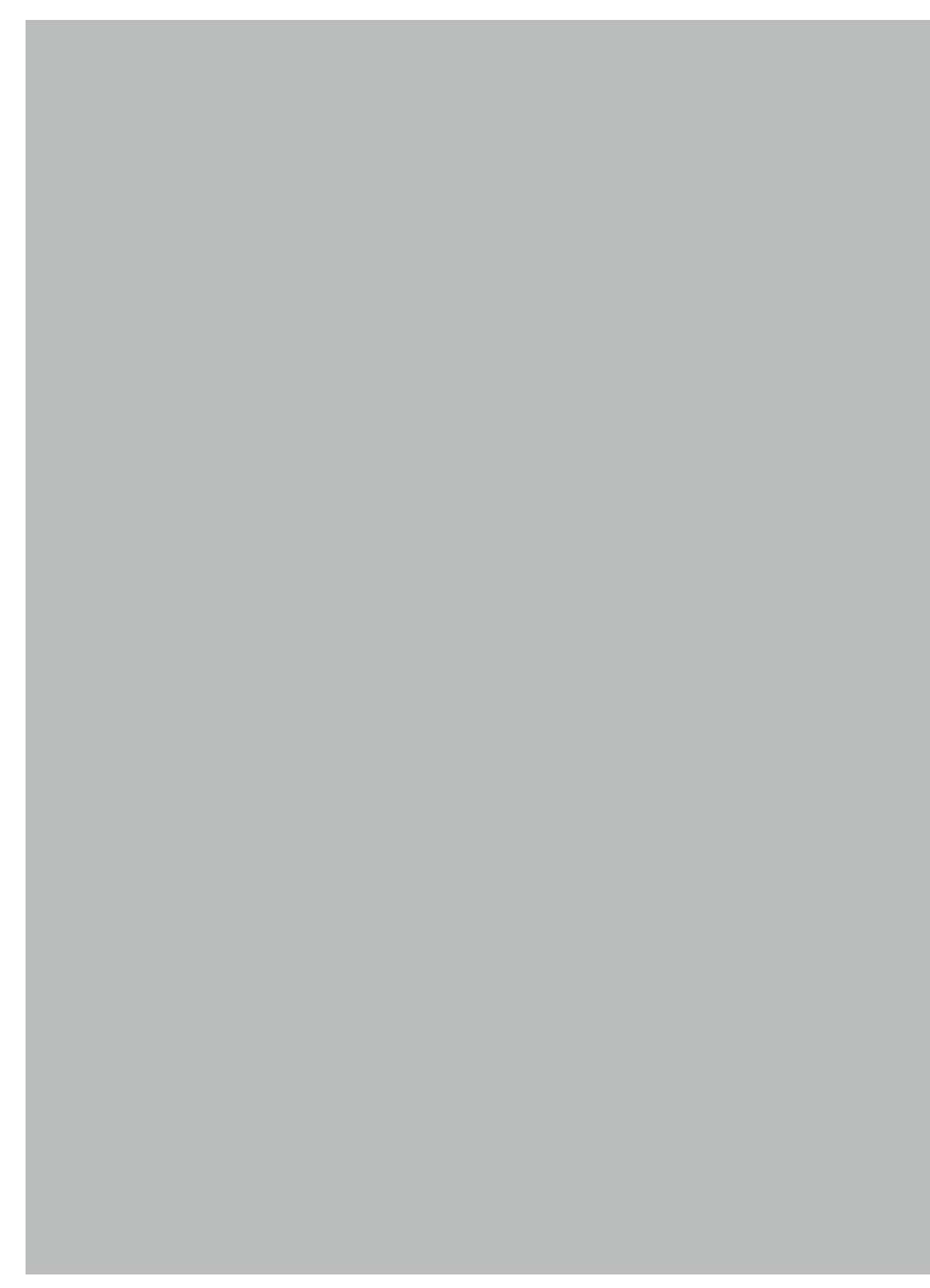

FIG. 4. LOUIS WAGNER. ALEXANDRA VON BERCKHOLTZ. 1845, LITHOGRAPH. PRIVATE COLLECTION.

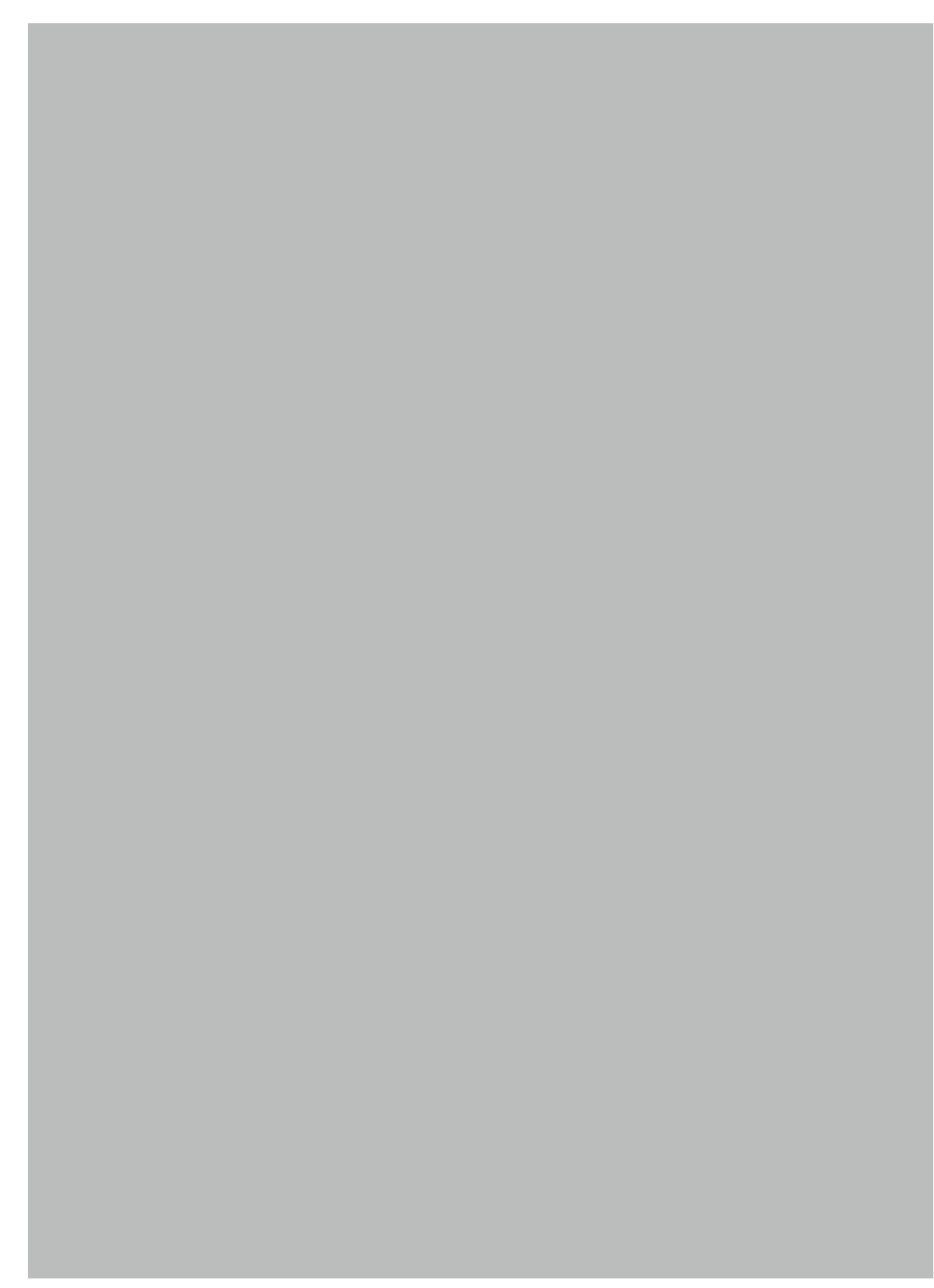

FIG. 5. ALEXANDRA VON BERCKHOLTZ. SLEEPING DOG IN ITS KENNEL. 1843, PENCIL ON PAPER, $30.9 \times 22.6$ CM. PRIVATE COLLECTION, ALLHARD VON LOESCH, BAD HOMBURG. 
of the easel (Fig. 4) in 1845, where the artist can be seen working on her mother's portrait.

In 2017, two folders formerly owned by Alexandra were discovered in a private collection in Bad Homburg. In addition to 96 watercolours, etchings and oil sketches created by Alexandra von Berckholtz or her artist friends, the folders also contain two pencil drawings which were realized during Wagner's lessons. The first one shows a sleeping dog in its kennel in a backyard with a gate in the background on the right (Fig. 5). The artist inscribed on the back: "cf. 25. Mai 1843. Carlsruhe." The other one - a sitting naked child seen from the back (Fig. 6), was drawn on 9 January 1844, and the serial number "No. 3" on the bottom right is an indication of the fact that the sheet must have originated from a drawing lesson.

Her first drawing known to date depicts Romanesque sacral architecture (Fig. 7), and was created on 20 March 1832. Nearly all the tentative lines are drawn by the help of a ruler - except for some parallel hatching, which reveals a very early stage of artistic creativity. At that time Alexandra von Berckholtz was ten years old.

\section{ORTENBERG/BADEN AND PARIS}

The Berckholtz family spent winters in Karlsruhe and summer months in Ortenberg/Baden, where Gabriel Leonhard had re-erected the castle between 1833 and 1843 with the help of the architect Friedrich Eisenlohr (1805-1854). The castle had been destroyed by the French king Louis XIV (1638-1715) in 1678. In the so-called artist's tower Alexandra had her studio until 1863; today it houses Ortenberg's registry office. A self-portrait shows the artist in thinker's pose in front of the easel in her studio (Fig. 8). ${ }^{18}$

From 1848 until 1854 Alexandra von Berckholtz studied in Paris, mainly at the studio of the historical painter Joseph-Nicolas RobertFleury (1797-1890), who taught her his stylistic mixture of maximal realism as far as a portrait is concerned and idealism in staging the content in an individual image. From 1855, Robert-Fleury was professor at the École Nationale Supérieure des Beaux-Arts, which at the time was not accessible for women. Besides, Alexandra's name can 


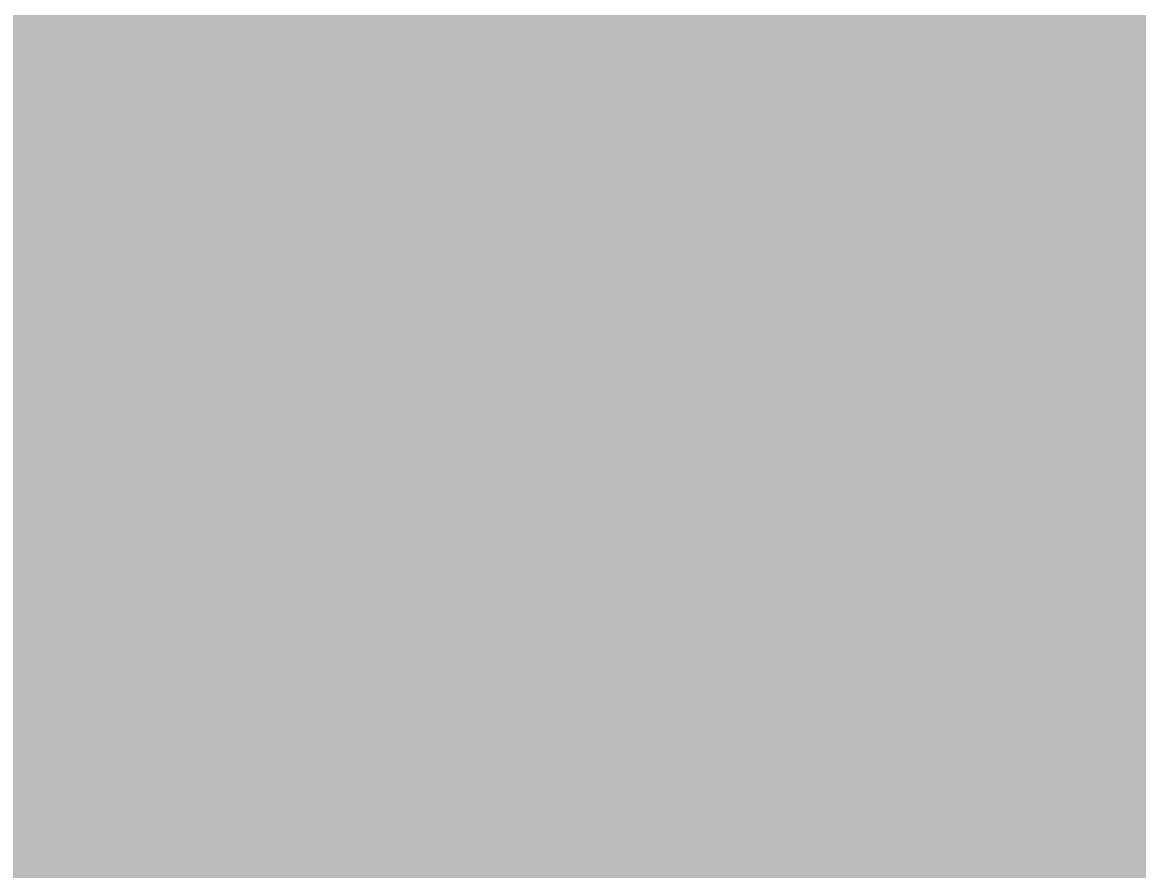

FIG. 7. ALEXANDRA VON BERCKHOLTZ. ITALIAN ARCHITECTURE. 1832, PENCIL ON PAPER, $8.3 \times 10.8$ CM. PRIVATE COLLECTION, ALLHARD VON LOESCH, BAD HOMBURG.

be found on a list of copyists at the Musée du Louvre on 11 May $1850 .{ }^{19}$ The copied picture is not known. The Crowning of Empress Josephine in Notre Dame, 1804 by Jacques-Louis David (1748-1825) might be a possibility in this respect, considering a gouache by Alexandra von Berckholtz in a private collection in Bad Homburg, which is an exact miniature copy of David's painting at the Louvre. ${ }^{20}$

19 Ho, Berckholtz (Berkholz), Alexandra von, 9-11; Gutgesell, Alexandra von Berckholtz. Malerin und Mäzenin im 19. Jahrhundert, 27; A rchives des Musées nationaux de Paris "LL 14 (1850-1853)", Registre des copistes, cartes de permission d'entrée, No. 286 (11th May 1850). 20 Natalie Gutgesell, "Die Malerin Alexandra von Berckholtz und ihre Familie, unter besonderer Berücksichtigung neu entdeckter Werke", Nachrichtenblatt der Baltischen Ritterschaften, 2
(2018), 29. 


\section{STUDIES WITH RICHARD LAUCHERT IN KARLSRUHE}

After having returned to Karlsruhe in 1854, Alexandra von Berckholtz worked together with the Hohenzollern court painter Richard Lauchert (1823-1868). ${ }^{21}$ He influenced her stylistically more than any other of her art teachers - considering the special view-frame of her portrayed persons, the psychological presentation of their physiognomies, and the material character of the textiles in her pictures. It has often been stated, even in articles published during her lifetime, that Franz Xaver Winterhalter (1805-1873) was one of Alexandra von Berckholtz' teachers, ${ }^{22}$ which might be probable with regard to stylistic features, but conclusive evidence is lacking. Lauchert was Winterhalter's former pupil and a close friend of the artist, who sometimes arranged orders for him. An example is Lauchert's portrait of Princess Alexandra of Denmark (1844-1925) in 1862/63 before her marriage to King Edward VII (1841-1910), the eldest son of Queen Victoria (1819-1901) and Prince Consort Albert of Saxe-Coburg and Gotha (1819-1861). ${ }^{23}$

Richard Lauchert himself also arranged orders for Alexandra von Berckholtz, such as a portrait of Katharina von HohenzollernSigmaringen (1817-1893) (Fig. 9) in 1854, which is today at the Beuron Abbey, where the Princess founded a new Benedictine community in 1863, out of which emerged the Beuron Art School. ${ }^{24}$ On the back of the painting Alexandra indicated that the image was produced as a copy of one of Lauchert's portraits of Princess Katharina. Thus far, three of his paintings of Katharina von Hohenzollern have been known, ${ }^{25}$ they do not, however, include the original one copied by

21 Ulrich Feldhahn, "Ein Künstler der 'höchsten Kreise‘. Zum 150. Todestag des Porträtmaler Richard Lauchert (1823-1868)", Schwäbische Heimat 4 (2018), 428-435, esp. 435.

22 E.g. Almanach der Maler und Bildhauer Deutschlands und Oesterreich-Ungarns (Stuttgart: Greiner \& Pfeiffer, 1890), 20.

23 Oil on canvas, $160.3 \times 112.5 \mathrm{~cm}$, Her Majesty Queen Elizabeth II, Royal Collection Trust Inv-No. RCIN 407236; Gutgesell, Alexandra von Berckholtz. Malerin und Mäzenin im 19. Inv.-No. RCIN 407236; Gutgesell,
Jahrhundert, 153-154, Picture 212 .

24 Hubert Krins, Die Kunst der Beuroner Schule. Wie ein Lichtblick vom Himmel (Beuron Beuroner Kunstverlag, 1998); Harald Siebenmorgen, Die Anfange der Beuroner Kunstschule. Peter Lenz und Jakob Wüger 1850-1875. Ein Beitrag zur Genese der Formalabstraktion in der Moderne (Sigmaringen: Thorbecke, 1983); Gutgesell, Alexandra von Berckholtz. Malerin un Mäzenin im 19. Jahrhundert, 226-227, No. 14

25 Half-length Portrait, oil on canvas, $71 \times 61 \mathrm{~cm}, 1848$, Schloss Sigmaringen, Bilderkamme nv.-No. Ho 14; Half-length Portrait, oil on canvas, $70 \times 50 \mathrm{~cm}$, formerly Wittelsbache 1850, formerly Waldenburg Castle, burned on 16 April 1945
Alexandra von Berckholtz. Lauchert's original oval portrait (Fig. 10) - which he painted soon after the death of Katharina's husband Kar von Hohenzollern-Sigmaringen (1785-1853) - was discovered at an auction at Casa d'Aste Capitoliumart in Brescia on 18 February $2016^{26}$ from a private collection in Trieste. Information on the depicted person and on the painter is on the reverse: "Catherine / Princess of Hohenzollern-Sigmaringen / a born Princess of Hohenlohe / Waldenburg and Schillingsfuerst / Born on 19 January 1817 / Painted by / RLauchert / 1853." Alexandra also presents Princess Katharina with her almost identical bust-length oval portrait in a black dress and with a widow's veil on her head, but with less mourning expressed on her face. Her eyes light up a bit and create the impression of female dignity.

Besides the Lauchert portrait, other new information on Alexandra von Berckholtz' work has been discovered, regarding the Winterhalter brothers. It is not only Franz Xaver, but his brother Hermann Winterhalter (1808-1891) who is also likely to have been Alexandra von Berckholtz' teacher. The indication on one of her drawings (Fig. 11) in the Bad Homburg collection provides possible evidence. In the centre of the given picture a young woman dressed in a white blouse, a blue skirt and a red cloth hanging down from her shoulders is standing on a hill in a landscape, next to a girl, on the left, holding large antlers. The woman is carrying a bundle of hay on her back and is surrounded by four deer, while two other deer are curiously approaching on the right. The inscription on the lower right edge contains the following information: "Hermann Winterhalter. Copy according to Lauchert." It can therefore be assumed that Alexandra's drawing as a copy of a painting by Hermann Winterhalter could have originated from Richard Lauchert's lessons. The oil painting in question with the title Landscape Study, whose present location is unknown, was definitely painted by Hermann Winterhalter. It was part of his heritage ${ }^{27}$ and one of the numerous different copies existing in the 19th century of The Forester's Family by Sir Edwin Landseer 26 Richard Lauchert, Mezza figura Catherine, oil on canvas, $43 \times 36 \mathrm{~cm}$, signed and dated
1853 , private collection; Old Masters and XIX Century, ed. by Casa d'Aste Capitolinum (Brescia: Casa d'Aste Capitolinum, 2016), No. 103. The author would like to thank Mr Giorgio Ruscon for all his help.

27 Painting no. 172, franzxaverwinterhalter.wordpress.com/works-by-hermannwinterhalter-1808-1891/ (accessed 31.10.2018). 


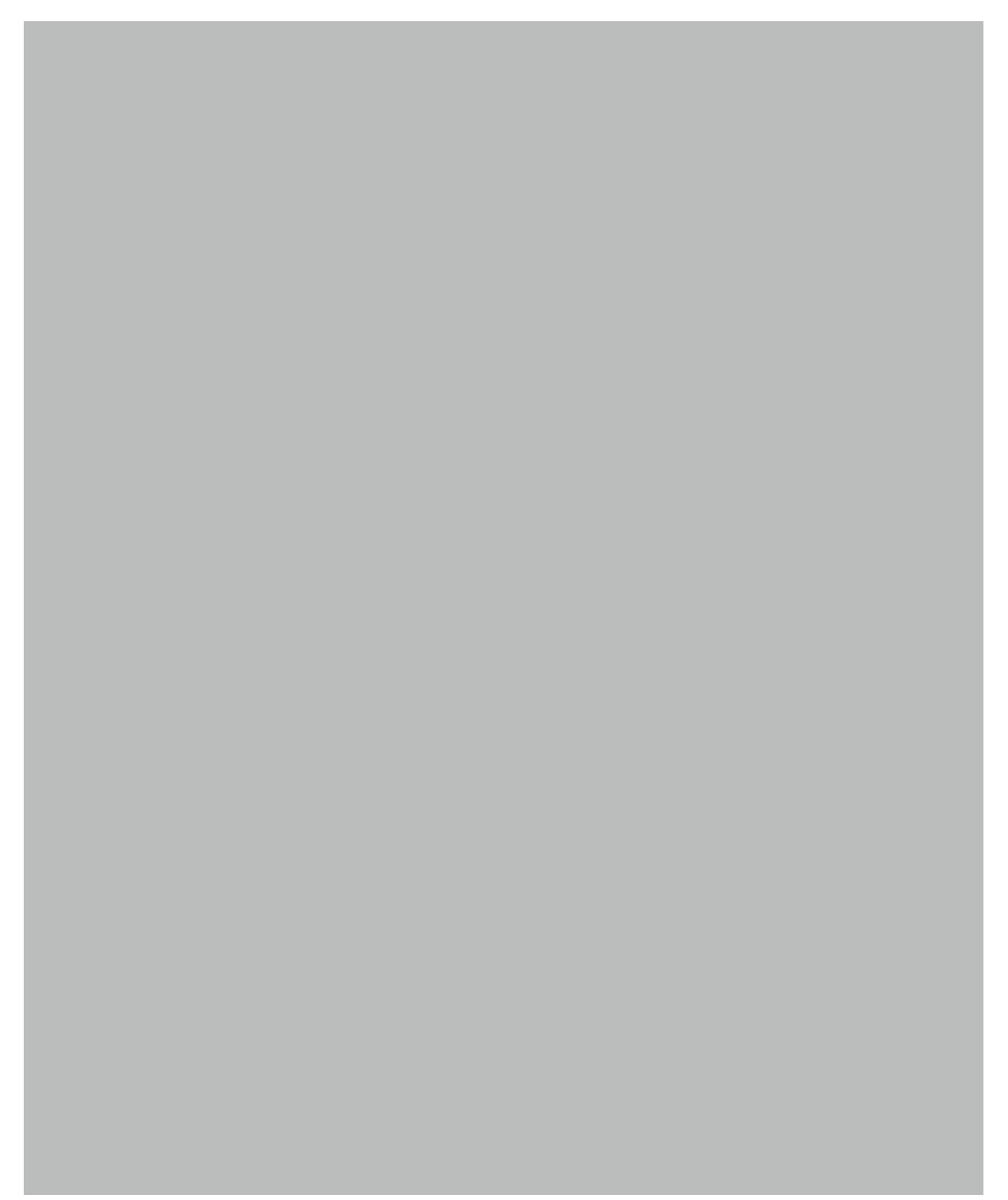

FIG. 9. ALEXANDRA VON BERCKHOLTZ. KATHARINA VON HOHENZOLLERN-SIGMARINGEN. 1854, OIL ON CANVAS, $64 \times 49$ CM. BEURON ABBEY.

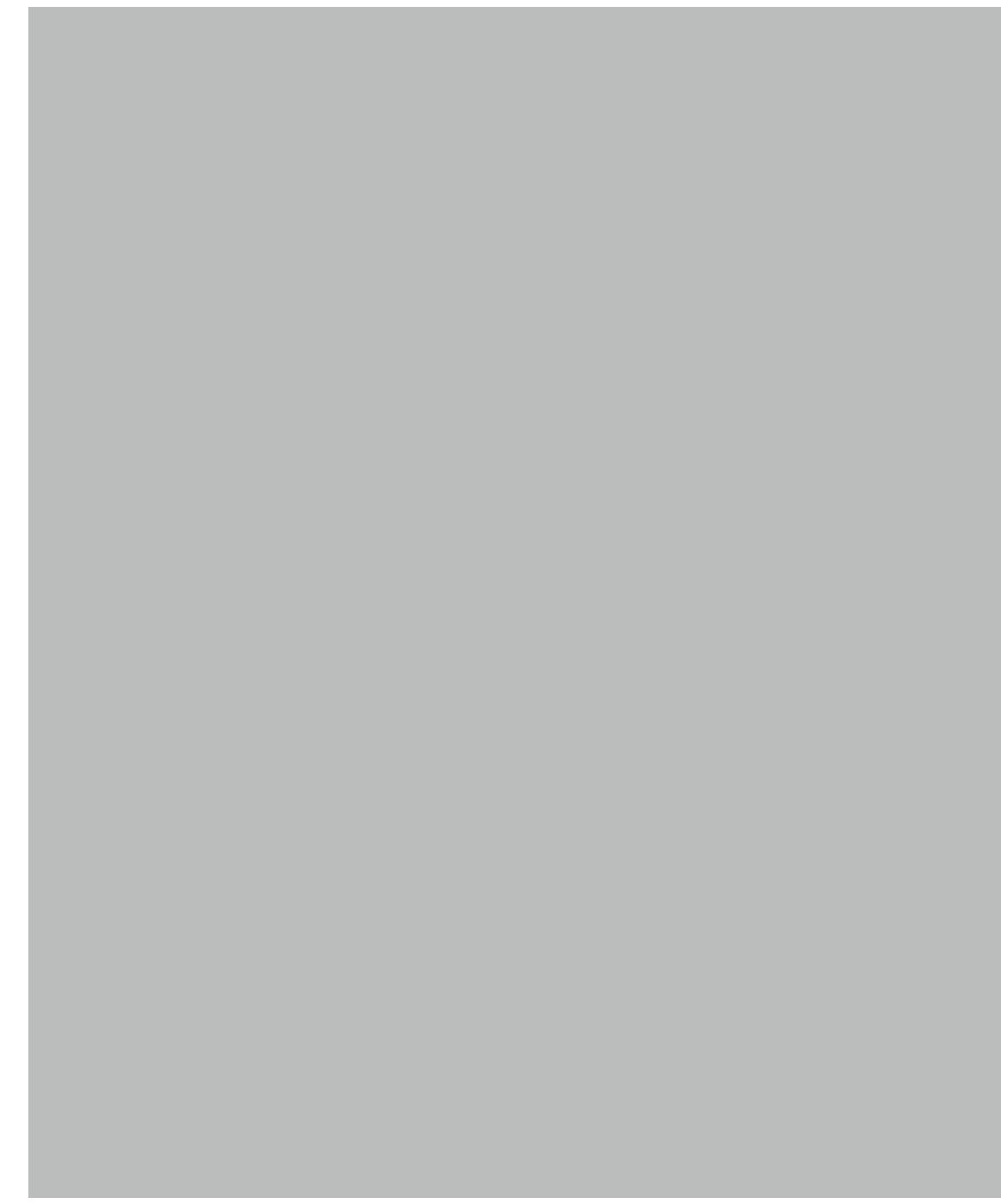

FIG. 10. RICHARD LAUCHERT. KATHARINA VON HOHENZOLLERN-SIGMARINGEN. 1853, OIL ON CANVAS, $43 \times 36$ CM. PRIVATE COLLECTION, CASA D'ASTE CAPITOLINUM BESCIA. 


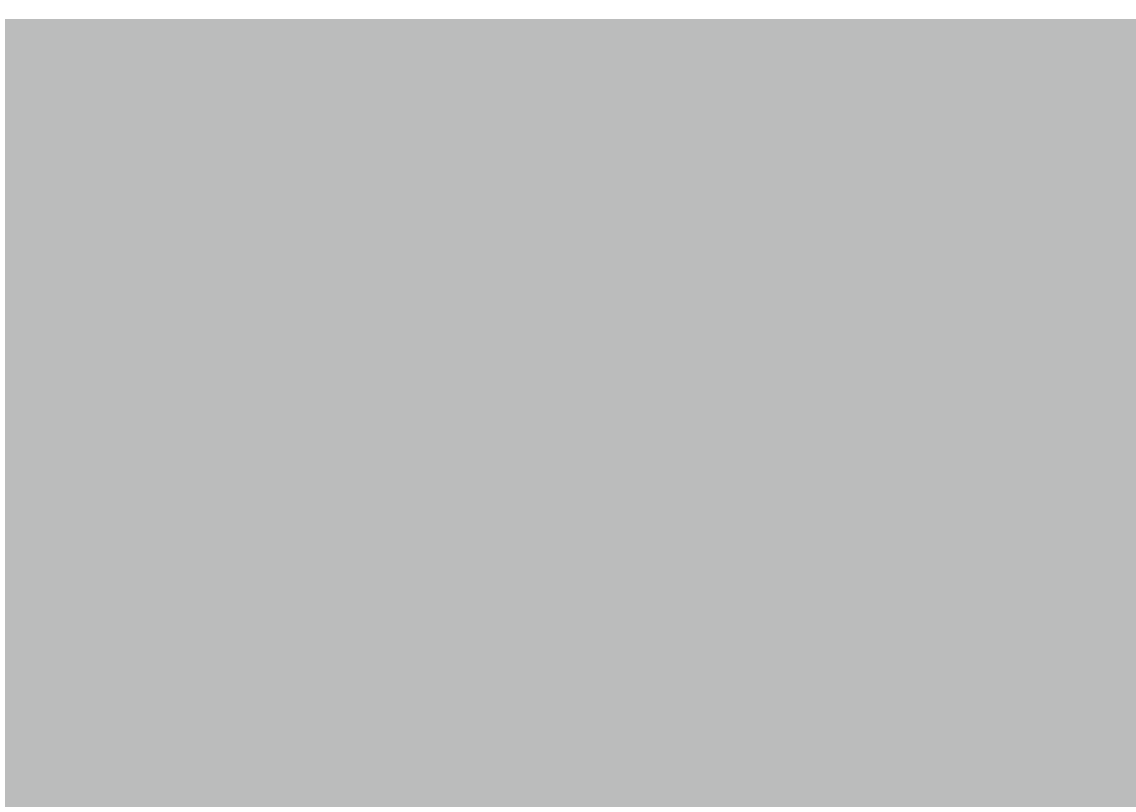

FIG. 11. ALEXANDRA VON BERCKHOLTZ. THE FORESTER'S FAMILY. PENCIL AND CRAYON ON PAPER, MOUNTED ON BROWN CARDBOARD, $20.4 \times 28.7$ / $35.8 \times 46$ CM. PRIVATE COLLECTION
ALLHARD VON LOESCH, BAD HOMBURG.

(1802-1873). The original painting was purchased by Leopold I, King of the Belgians (1790-1865) in 1849, and has never been exhibited. As Hermann Winterhalter portrayed members of the Belgian royal family, e.g. Princess Charlotte (1840-1927), ${ }^{28}$ the copy of Landseer's Forester's Family might have resulted from the occasion of his stay in Belgium.

Since 1855, Alexandra von Berckholtz took additional lessons at the studio of the historical painter Louis des Coudres (18201878) in Karlsruhe, and in 1862/63 she worked together with the Austrian genre and portrait painter Hans Canon (1829-1885), whose

28 Oil on canvas, $99 \times 66.8 \mathrm{~cm}, 1848$, Queen's Dressing Room \& Bathroom, Osborne House Her Majesty Queen Elizabeth II, Royal Collection Trust Inv.-No. RCIN 403674. Charlotte married the Archduke Ferdinand-Maximilian of Austria (born 1832) in 1857. He was proclaimed Empero of Mexico in 1864 and executed in 1867. most famous works include the portrait of Gabriel Leonhard von Berckholtz. ${ }^{29}$

\section{TRAVELS AND SKETCHBOOKS}

Throughout her life Alexandra often travelled abroad. Many of her trips can be reconstructed from her sketchbooks and from diary entries, such as the unpublished memoir of Luise von Schkopp (born 1853), who got to know Alexandra von Berckholtz, her sisters Sophie von Moltke (1810-1878), Elisabeth Offensandt (1813-1892), and her niece - Elisabeth's daughter - Alexandra (1840-1921) during a stay in Nice in autumn 1864. Luise von Schkopp, who was accompanied by her foster mother Pauline Gans Edle Herrin zu Putlitz, was painted twice by the artist in Nice. ${ }^{30}$ The first half-length portrait shows the eleven-year-old girl in semi-profile looking to the right in a thoughtful and introverted manner. Her blond shoulder-length hair is trimmed by a black band. She is wearing a black blouse with a white collar and standing in front of the sea. Due to the fact that her first portrait in her opinion did not bear much similarity to the depicted person, Alexandra von Berckholtz painted Luise von Schkopp a second time in a three-quarter portrait with a blue ribbon in her hair, a white blouse, and some more emphasis on the low position on the sea's horizon in the background.

Twenty years earlier Alexandra von Berckholtz had already painted her close friend Melanie von Campenhausen (1815-1901), ${ }^{31}$ who became Luise's mother-in-law in 1883 when she married Theophil von Barsewisch (1854-1938). The archives of the family von Barsewisch also preserve Alexandra's drawing and lithograph of Melanie's

29 Oil on canvas, $79 \times 63,2 \mathrm{~cm}$, signed and dated on lower left CANON. / 1863, Urban Gallery Karlsruhe Inv.-No. 60/0159; Franz Josef Drewes, Hans Canon (1829-1885): Werkverzeichnis und Monographie. 2 vols. (Hildesheim: Olms, 1994), 203, No. 72, Gutgesell, Alexandra von Berckholtz. Malerin und Mäzenin im 19. Jahrhundert, 31, Picture 30.

30 Both: oil on canvas, $25 \times 22 \mathrm{~cm}, 29.5 \times 23.5 \mathrm{~cm}, 1864$, private collection of Family von Barsewisch; Gutgesell 31-32, 232-235, No 17, 18 .

31 Watercolour painting over pencil, heightened with opaque white, $24.5 \times 20 \mathrm{~cm}, 1844$, Family Archives of Prof. Dr. Bernhard von Barsewisch Groß Pankow Inv.-No. CW 153; Gutgesell, 


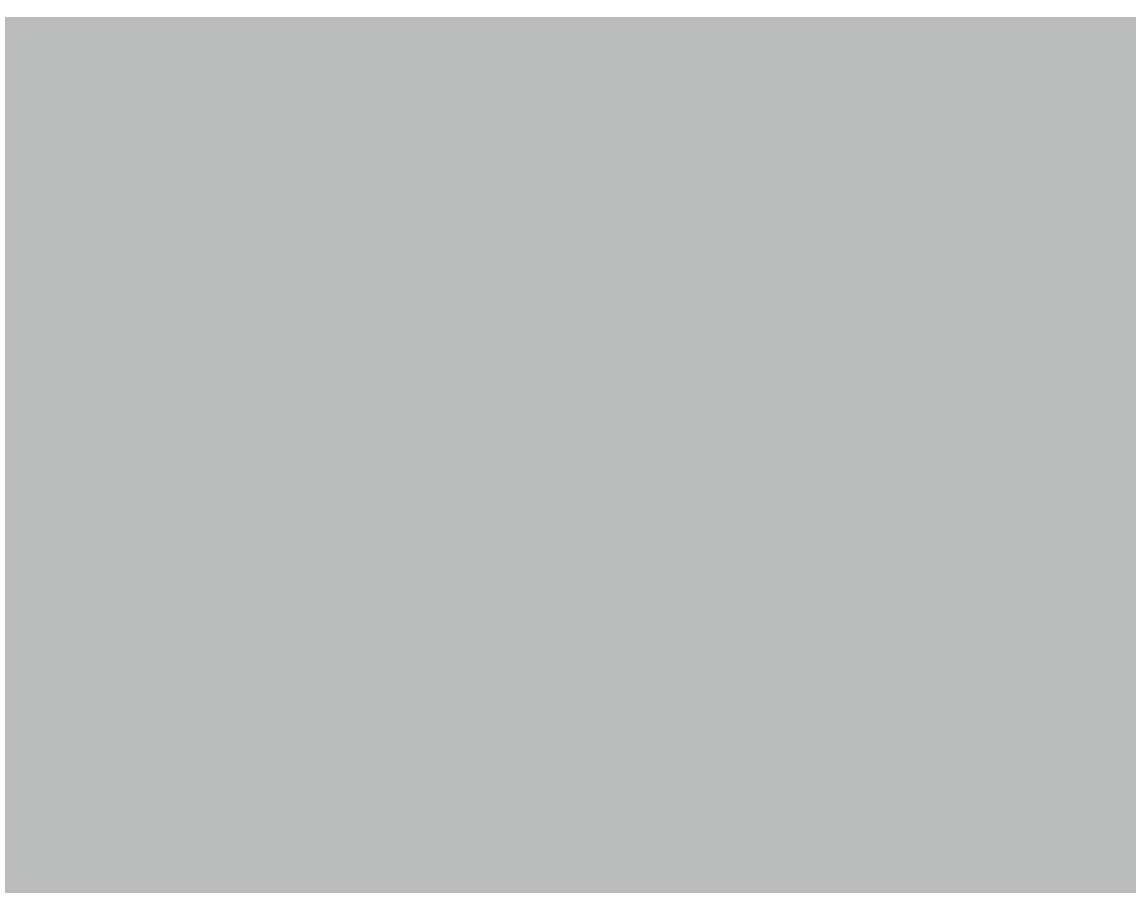

FIG. 12. ALEXANDRA VON BERCKHOLTZ. INTERIOR SCENE. 1861, PENCIL ON PAPER, $17 \times$ 22.3 CM. PRIVATE COLLECTION, FRANKFURT/MAIN

brother Arthur von Campenhausen (1818-1846), , $^{32}$ and a photograph of another drawing of his sister Adele von Campenhausen (1819-1871). ${ }^{33}$

Numerous other travels took Alexandra von Berckholtz to the Czech Republic, where she visited her niece Olga (1832-1906) at Velké Březno castle in Bohemia. Olga was the daughter of her eldest sister Anna Natalie von Berckholtz, who married Paul Friedrich von Moltke (1786-1846) in 1830. He and general field marshal Helmuth von Moltke (1800-1891) shared a grandfather. Von Moltke had been

32 Pencil on paper, $13 \times 10 \mathrm{~cm}, 1847$, Family Archives of Prof. Dr. Bernhard von Barsewisch, Groß Pankow Inv.-No. CW 160; Lithograph, $17 \times 12 \mathrm{~cm}$, Inv.-No. CW 161; Gutgesell, Alexandra von Berckholtz. Malerin und Mäzenin im 19. Jahrhundert, 282-283, No. 42, Picture 305.

$3310 \times 6 \mathrm{~cm}, 1846$, Family Archives of Prof. Dr. Bernhard von Barsewisch, Groß Pankow Inv.-No. CW 162; Gutgesell, Alexandra von Berckholtz. Malerin und Mäzenin im 19. Jahrhundert, at the service of the Russian Tsar from 1809 until 1811 as a diplomat in Königsberg and Berlin. Since 1816 he worked in Torino and from 1829 onward in Karlsruhe. Their only daughter Olga married Count Anton Maria Johann Chotek von Chotkow und Wognin (18221883), minister of the Austro-Hungarian Empire in St. Petersburg, at Ortenburg castle in 1851. For most of the year the couple lived in Velké Březno, where Alexandra von Berckholtz annually spent many weeks, e.g. in September 1867. Her sketchbooks contain many portraits of family members, such as Olga's daughters Marie (18551941) and Olga Chotek (1860-1934), ${ }^{34}$ and her sister-in-law Vilemína 'Minzi' Chotek (1838-1886). ${ }^{35}$

In a recently discovered sketchbook, in a collection in Frankfurt/ Main, Alexandra presents a drawing of an interior at Velké Březno castle (Fig. 12). A woman surrounded by two children is sitting on the left in a large salon with two high round arched windows in the back. On the right, a man and a woman are playing the piano. The scene is located and dated lower right with "Grosspriesen $24 \mathrm{Mai}$ 1861". On the same day Alexandra also drew her niece Olga (Fig. 13) in her sketchbook. Maybe the drawing served as a model for the execution of a portrait?

\section{SOPHIE VON MOLTKE'S PORTRAIT DISCOVERED}

Another recent discovery was preceded by lengthy and intensive searches, and it concerns an oil painting of Alexandra's second eldest sister Sophie von Berckholtz (Fig. 14). After the death of her sister, Sophie married her widowed brother-in-law Paul Friedrich von Moltke in 1837 and adopted her niece Olga. In 1855, Sophie moved to Munich, where she bought a house in Gabelsbergerstrasse 85, in which Alexandra von Berckholtz also lived from 1863. The existence of the portrait painted in 1866 was proven by information in different articles published during Alexandra's lifetime. ${ }^{36}$ An oil painting of

34 City Archives of Offenburg, Inv.-No. 26/21/019; Gutgesell, Alexandra von Berckholtz. Malerin und Mäzenin im 19. Jahrhundert, 55, 322-323, No. 62

35 City Archives of Offenburg, Inv.-No. 26/21/019; Gutgesell, Alexandra von Berckholtz. Malerin und Mäzenin im 19. Jahrhundert, 55, 326-327, No. 64.

36 E.g. Meyer, Allgemeines Künstler-Lexicon, 586-587; Friedrich von Boetticher, Malerwerke des 19. Jahrhunderts, vol. 1 (Dresden: Boetticher, 1895), 84; Gutgesell, Alexandra von Berckholtz.
Malerin und Mäzenin im 19. Jahrhundert, 437, No. 77. 


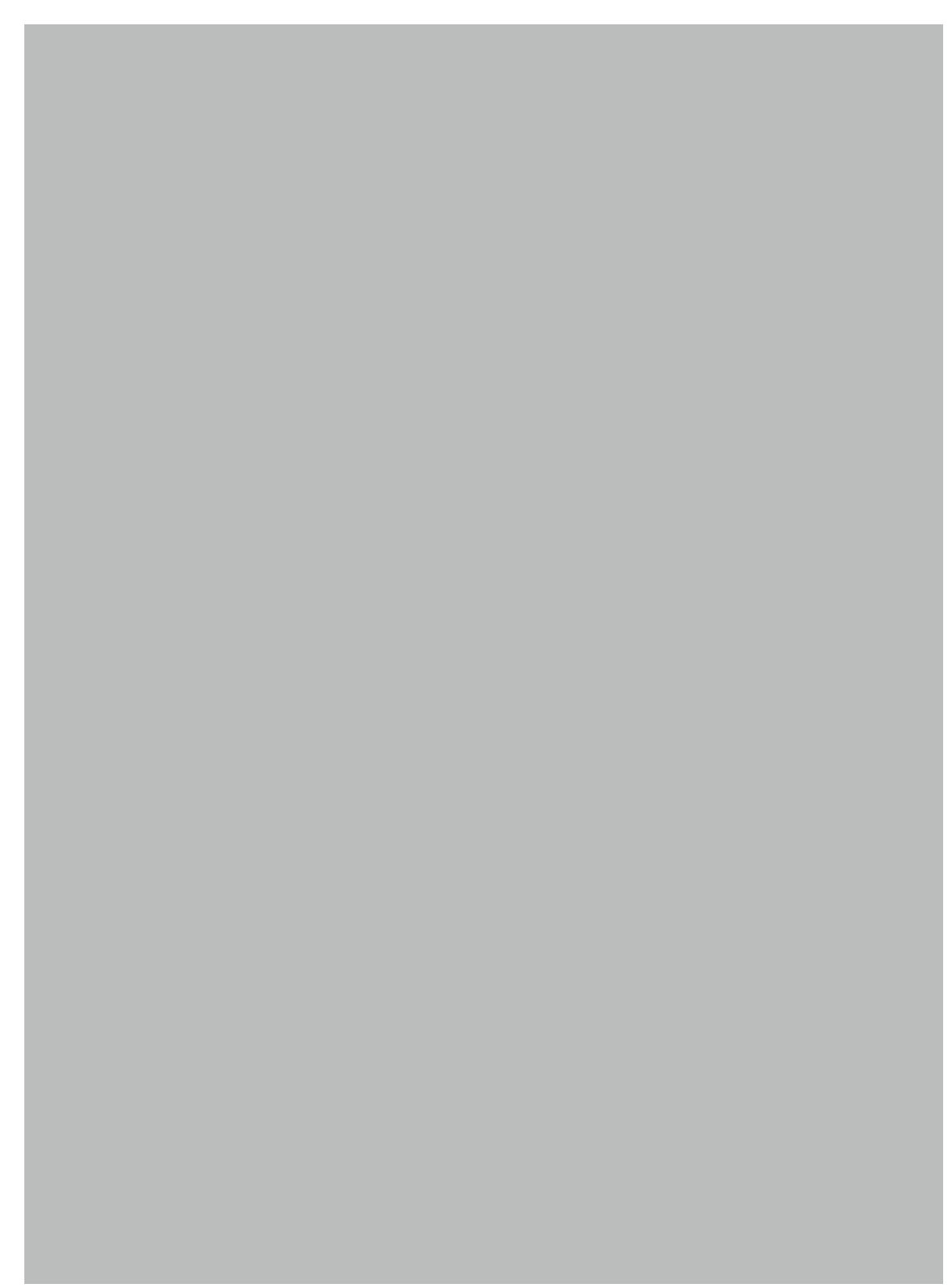

FIG. 13. ALEXANDRA VON BERCKHOLTZ. OLGA CHOTEK. 1861, PENCIL ON PAPER, $22.3 \times 17$ CM. PRIVATE COLLECTION, FRANKFURT/MAIN.

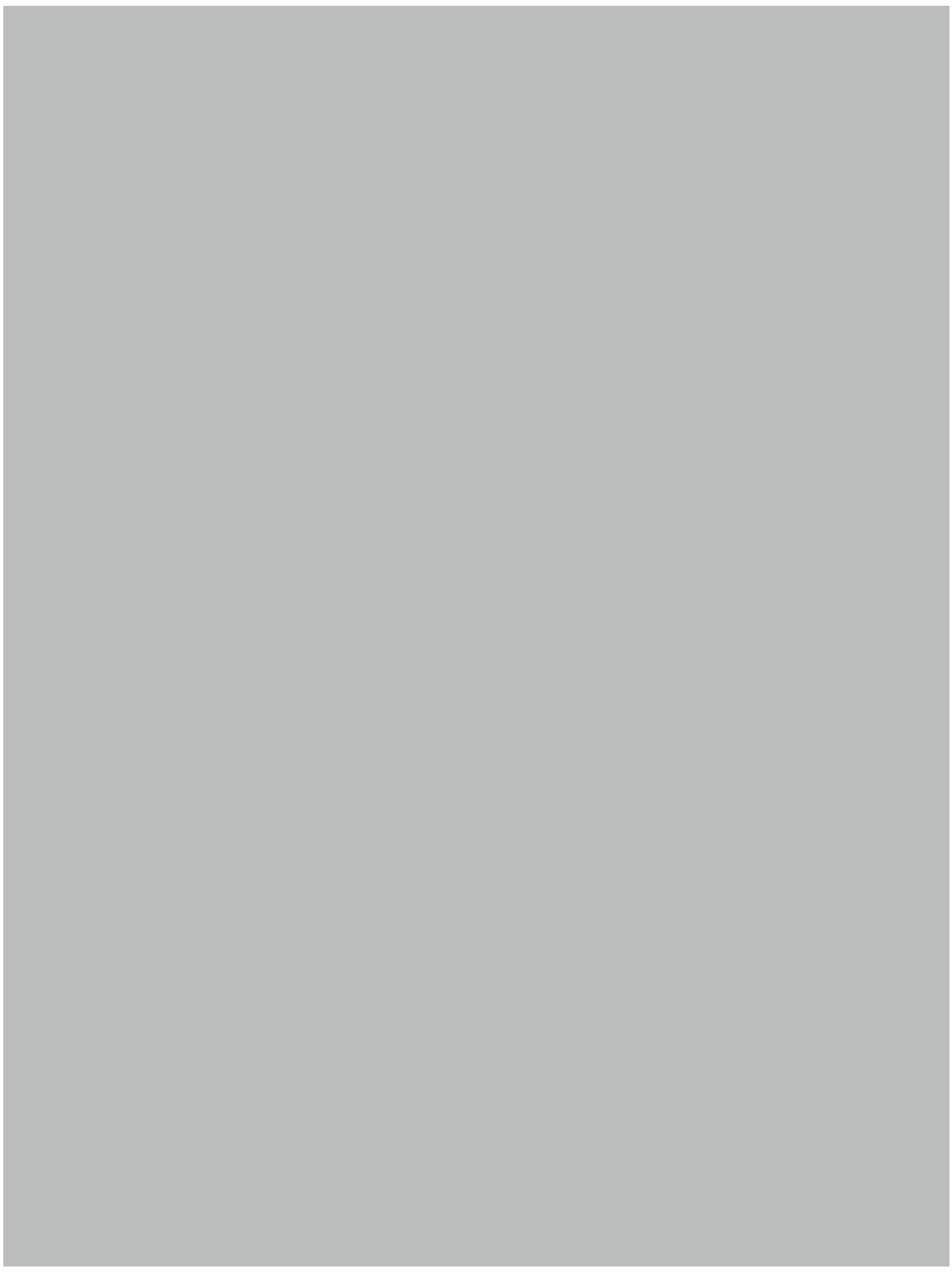

FIG. 14. ALEXANDRA VON BERCKHOLTZ. SOPHIE VON MOLTKE. OIL ON CANVAS, $57 \times 48$ CM. PRIVATE COLLECTION, FRANKFURT/MAIN. 
Sophie von Moltke is today part of a private collection in Frankfurt/ Main. This particular portrait, however, is an earlier one, for the depicted woman must - considering Sophie's year of birth - surely be younger than 56 years. This evidence is also based on a photograph of Sophie von Moltke which was taken between 1860 and 1878 .

\section{OTHER EXEMPLARY FAMILY PORTRAITS}

Alexandra also painted her sister Olga of whom nothing but her birth baptism, and death are known. The first portrait, created in 1845, belongs to the collection of the Ritterhaus Museum Offenburg. The location of another one dating from around 1847 is unknown. ${ }^{37}$ With her picture Alexandra von Berckholtz gives her sister an identity, and therefore she saves her from being forgotten.

Two almost identical portraits depicting Elisabeth von Berckholtz in 1860 and 1861 found their way into Augustinermuseum Freiburg and the City Gallery of Karlsruhe. ${ }^{38}$ In 1839 Elisabeth married the widowed merchant Carl Ferdinand Offensandt (1803-1857) from Bremen. They had two daughters - Alexandra and Sophie Natalie (1846-1848), and two sons - Wilhelm (1843-1909) and Leonhard Carl (born and died in 1848). Thirty years after her husband's death, Elisabeth's hereditary peerage was restored by Grand Duke Friedrich I of Baden (1826-1907), after her brother Jacob Johann had died in 1887. Henceforth she bore the name Elisabeth Offensandt von Berckholtz.

Alexandra's painting of her niece Alexandra Offensandt shows explicit similarities to Richard Lauchert's portrait of the 15-year-old Princess Stephanie von Hohenzollern-Sigmaringen (1837-1859) in the Art Collection of Hohenzollern. She presents her with a wreath of white flowers on her head, two strings of white pearls around her neck, blue silk dress with white lace that covers the décolleté. ${ }^{39}$ In 1867, she married the royal Prussian Major and Minister of the State of Baden Johann Ferdinand von Bodmann (1839-1920). Together with 37 Gutgesell, Alexandra von Berckholtz. Malerin und Mäzenin im 19. Jahrhundert, 212-213,
No. 7.

38 Oil on canvas, $107 \times 80 \mathrm{~cm}, 1860$, Augustinermuseum Freiburg Inv.-No. $05807 \mathrm{~B}$; oil on Inv-No. 68/032. Gutgesell, Alexandra von Berckholtz. Malerin und Mäzenin im 19. Jahrhundert, 206-209, No. 4, 5.

39 Oil on canvas, $107 \times 80 \mathrm{~cm}, 1860$, Augustinermuseum Freiburg Inv.-No. 05808B; Gutgesell, Alexandra von Berckholtz. Malerin und Mäzenin im 19. Jahrhundert, 210-211, No. 6. her brother Wilhelm, Chamberlain and Chateau Commissioner of the Grand Duke of Baden, she donated a plot of land in Vorholzstrasse 3548 in Karlsruhe to establish a home for elderly women who needed care. Wilhelm bequeathed in his testament 700,000 marks for the foundation of the retirement home Berckholtz-Stiftung, which still exists in Karlsruhe today.

As far as Wilhelm Offensandt von Berckholtz is concerned, not a single oil portrait has been discovered so far; there are two drawings which show him as a three-year-old boy ${ }^{40}$ and a 22 -year-old man. ${ }^{41}$ In addition to these, the collection in Bad Homburg includes a charcoal drawing of Wilhelm's bust-portrait on cardboard (Fig. 15), which is the preliminary stage for an oil painting. ${ }^{42}$ The location of the oil painting is at present unknown.

Two different portraits of the artist's brother Jacob Johann von Berckholtz have remained in the Town Hall of Ortenberg/Baden ${ }^{43}$ and in the private collection in Bad Homburg (Fig. 16). Whereas in the former Jacob is around 35 years old, he is younger in the latter, compared to a drawing by Rudolph Kuntz (1798-1848), which presents Jacob Johann in the uniform of a lieutenant of the Second Cavalry Regiment of Württemberg in $1840 .{ }^{44}$ Other evidence is given by a lithograph by Godefroy Engelmann (1788-1839) of Gustav Nehrlich's (1807-1840) portrait presenting Gabriel Leonhard, Barbara von Berckholtz and their son. The family portrait dates from 1835, at that time Jacob was 20 years old. ${ }^{45}$ Alexandra's oil painting shows her brother at approximately that age. It can be assumed that she painted $40 \quad$ Pencil on brown paper with white heightening, $18.7 \times 15.9 \mathrm{~cm}, 1846$, City Archives of
Offenburg Inv.-No. 26/02/241; Gutgesell, Alexandra von Berckholtz. Malerin und Mäzenin im 19. Jahrhundert, 280-281, No. 41 .

41 Pencil on paper, $18.9 \times 12 \mathrm{~cm}$, dated lower left 18 Aug. 1875., Sketchbook from 1875, City Archives of Offenburg Inv.-No. 26/21/021; Gutgesell, Alexandra von Berckholtz. Malerin und Mäzenin im 19. Jahrhundert, 75 , Picture 81

42 Gutgesell, Die Malerin Alexandra von Berckholtz und ihre Familie, unter besonderer Berücksichtigung neu entdeckter Werke, 28.

43 Oil on canvas, $84 \times 75 \mathrm{~cm}$, around 1850; Gutgesell, Alexandra von Berckholtz. Malerin und Mäzenin im 19. Jahrhundert, 214-215, No. 8.

44 Reproduction of the original drawing, pencil on paper, $50 \times 38.7 \mathrm{~cm}$, Town Hall, Ortenberg Baden; Gutgesell, Alexandra von Berckholtz. Malerin und Mäzenin im 19. Jahrhundert, 214 216, Picture 273.

45 Gustav Nehrlich (Inventor), Godefroy Engelmann (Lithograph), $28.24 \times 36.6 \mathrm{~cm}$, signed and dated on lower left $G$. Nehrlich 1835, City Archives Karlsruhe Inv.-No. 8/PBS III 1878 Gutgesell, Alexandra von Berckholtz. Malerin und Mäzenin im 19. Jahrhundert, 58, Picture 63. 


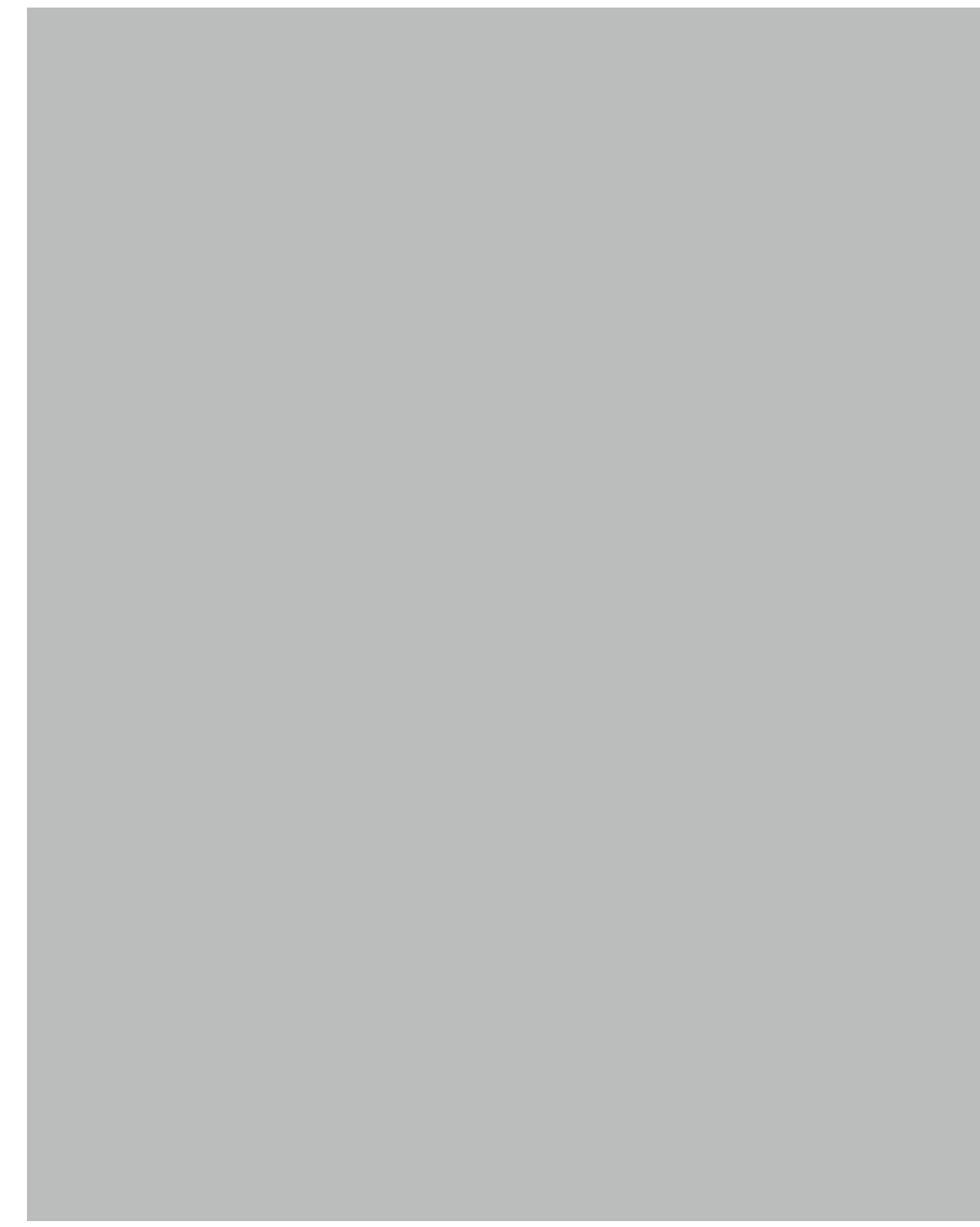

FIG. 15. ALEXANDRA VON BERCKHOLTZ. WILHELM OFFENSANDT VON BERCKHOLTZ. CHARCOAL ON CARDBOARD, $51.5 \times 42$ CM. PRIVATE COLLECTION, ALLHARD VON LOESCH, BAD HOMBURG.

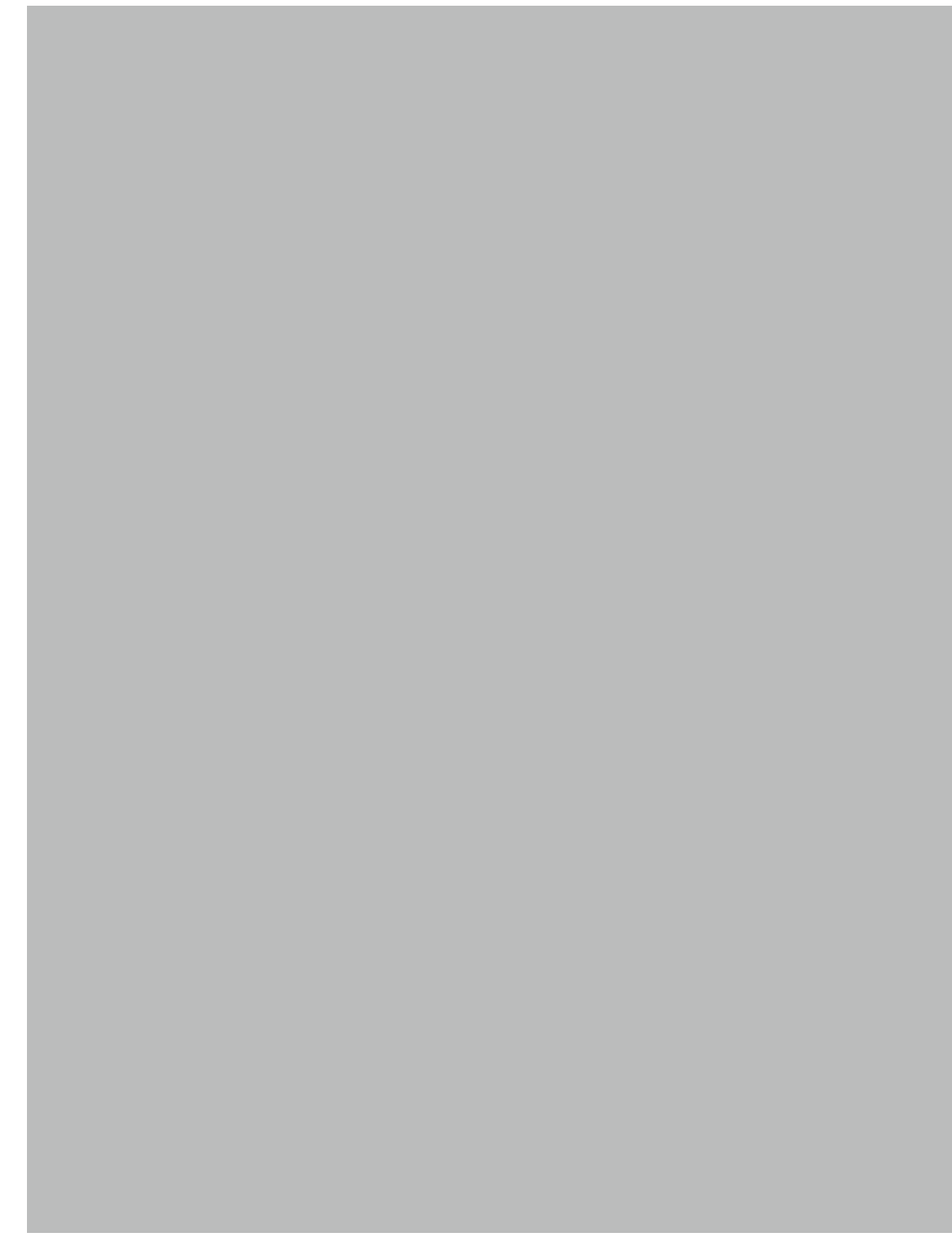

FIG. 16. ALEXANDRA VON BERCKHOLTZ. JACOB JOHANN VON BERCKHOLTZ. OIL ON CANVAS, $49 \times 33.5$ CM. PRIVATE COLLECTION, ALLHARD VON LOESCH, BAD HOMBURG. 


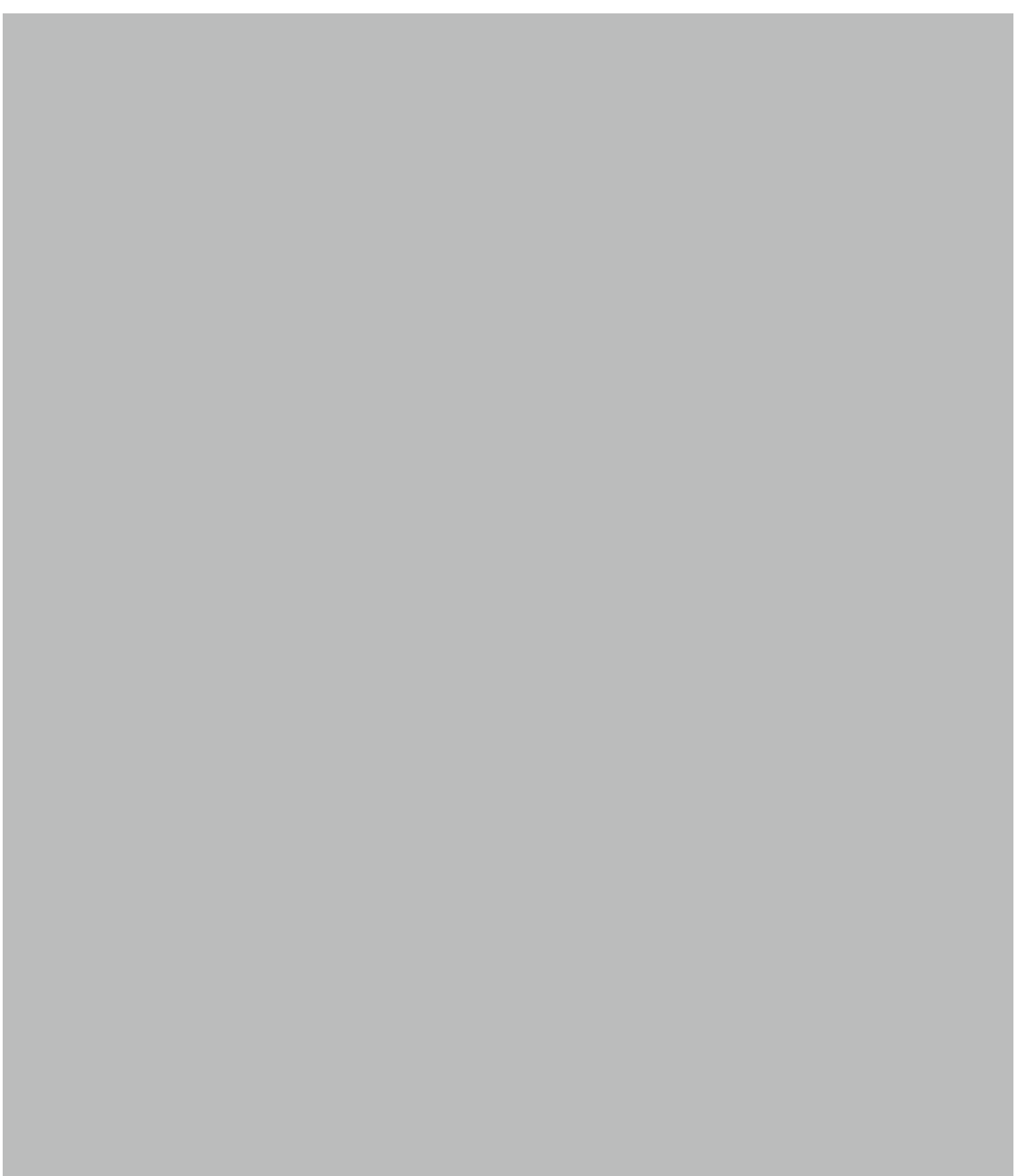

FIG 17. ALEXANDRA VON BERCKHOLTZ. EMMA VON BERCKHOLTZ. OIL ON CANVAS, $81 \times$ 70 CM. PRIVATE COLLECTION, FRANKFURT/MAIN.

it later and according to a graphic model, because it was just in the beginning of the 1840s and since her studies at Louis Wagner's that she had started painting her first oil pictures. Previously created portraits in oil are thus far not known. Jacob is presented at the age of about 16 to 20. Whether Alexandra painted him from life cannot exactly be said, because no reliable records of the years between 1831 and 1835 are available. Alexandra painted the background in single and quick brushstrokes which are clearly visible, but the subtle brushwork in which she realized the face, on the contrary, hints at Louis Wagner's style. His oil portrait of an unknown gentleman in an American private collection provides an analogy. ${ }^{46}$ Stylistically, this leads to the possible assumption that Alexandra painted her brother under Wagner's aegis, whom she got to know after 1841.

In 1849, Jacob Johann von Berckholtz married Emma Offensand (1829-1851), the daughter of his brother-in-law Carl Ferdinand Offensandt, husband of his sister Elisabeth. Emma was Ferdinand's daughter and only child from his first marriage with Luise Mohr (1800-1830) in Bremen. Alexandra painted Emma in 1850 in a headand-shoulders portrait with three-quarter profile to the left. Her brown hair is pinned up. She is wearing a grey silk dress with a red rose at the low neckline and a stole of white lace around her upper arms, and she is looking directly at the spectator. In addition to the picture described above, which is located in the Town Hall in Ortenberg, together with the half-length portrait of her husband Jacob Johann, last year another copy of the oil painting also made by Alexandra von Berckholtz was discovered in a private collection in Frankfurt/Main (Fig. 17). In this picture, Emma's facial characteristics are more delicate, the shimmering on the surface of the cloth is more brilliant and the rose on the dress is pink. Maybe the second portrait was painted in memory of Emma after her early death at the age of 22? The couple had one son, Jacob Leonhard Carl (1851-1854), who lost his life on the day his mother died, on 6 October. He was buried three days later in the family crypt in the cemetery of Ortenberg, as Alexandra wrote in her diary on 9 October $1854 .{ }^{47}$ 46 Oil on canvas, $26 \times 21 \mathrm{~cm}$, signed and dated on the left L. Wagner 1837; Winter Estates
Auction. New Orleans 2003 (New Orleans: Neal Auction Company, 2003), 93, No. 932, Abb The author would like to thank Ms Michelle LeBlanc Leckert, Vice President of Neal Auction Company, for her support in this respect.

47 "Beerdigung von Leon von Berckholtz in der Familiengruft auf dem Ortenberger Friedhof das Kind." City Archives Offenburg Berckholtz-Nachlass; Gutgesell, Alexandra von Berckholtz.
Malerin und Mäzenin im 19. Jahrhundert, 312-313. 


\section{ARTISTIC CIRCLE IN MUNICH}

On 29 October 1863 Alexandra von Berckholtz moved to Munich, where she lived in Gabelsbergerstrasse 85 until her death. Sophie von Moltke was the owner of the house, where Alexandra inhabited the second floor. She had regular contact with the prominent historical painter Carl Theodor von Piloty (1826-1886), his pupil Alexander von Liezen-Mayer (1839-1898), and the circle of the master painter Franz von Lenbach (1836-1904). In his early work von Lenbach concentrated on landscape and genre painting. Inspired by the French school of Barbizon, he practiced open-air painting, close observation of nature and capture of the decisive moment. Alexandra von Berckholtz had not focused on landscape painting before. The sceneries and buildings in her sketchbooks were mostly travel notes and souvenirs for herself. As an example, there are the 16 drawings created between 3-16 August 1842 on a journey to Switzerland, where she visited Lausanne, Vevey, Chillon on Lake Geneva, Bulle, Grindelwald, and Thun. ${ }^{48} \mathrm{~A}$ sketchbook dating from the 1860s mainly contains landscape studies, large part of which is dedicated to the surroundings of Munich, ${ }^{49}$ e.g. the mountains, the forests, or the vicinity of the Tegernsee Abbey. The pencil lines are broad, more densely composed and evoke a darker atmosphere of the sceneries. The drawings arouse the impression of having been created out of pure engagement with the subject matter The pictures were not primarily realized as mere studies, but as items worthy of representation in their own right. Due to the fact that this idea corresponds to von Lenbach's concept of landscape, Alexandra's drawings could have resulted from a cooperation with the master painter.

In 1869 Alexandra von Berckholtz took part in the First International Exhibition in Crystal Palace in Munich with her portrait of Ms. Florence Osborn..$^{50}$ The whereabouts of the painting are unknown

48 Sketchbook 1841-1846, City Archives of Offenburg Inv.-No. 26/21/015; Gutgesell, Alexandra von Berckholtz. Malerin und Mäzenin im 19. Jahrhundert, 124-127, Pictures 165-169.

49 Sketchbook 1866, City Archives of Offenburg Inv.-N0. 26/21/020; Gutgesell, Alexandra von Berckholtz. Malerin und Mäzenin im 19. Jahrhundert, 35-36, 386-395, Pictures 37-40, №. 94-98.

50 Katalog zur I. Internationalen Kunstausstellung im Königlichen Glaspalaste zu München 20. Juli bis 31. Oktober 1869 (München: Dr. C. Wolf \& Sohn, 1869), 41, No. 981; Paul Th. Falck, "Die Portaitmalerin Alexandra von Berckholtz", Duna Zeitung, 123 (5th June 1899); Allgemeine Zeitung, 300 (27th October 1869); Gutgesell, Alexandra von Berckholtz. Malerin und Mäzeni im 19. Jahrhundert, 37-38. today. Other exhibitions where she presented her works of art were the International Exhibitions in Munich in 1888, ${ }^{51} 1889,,^{52} 1890,{ }^{53} 1891,{ }^{54}$ $1893,{ }^{55} 1894,{ }^{56}$ and the Art Exhibition in Berlin in 1897.57 At the latter, Maximilian of Baden (1867-1929), son of Margrave Wilhelm (18291897), bought Alexandra's painting. His art collection, which was sold at an auction on 5-21 October 1995 by Sotheby's Baden, ${ }^{58}$ also included two other paintings by Alexandra von Berckholtz - Floral Still Life With a Wine Glass and Still Life of Roses - which are today part of a private collection in Ortenberg. ${ }^{59}$ In 1881, the Artists' Association of Munich organized an individual exhibition for Alexandra von Berckholtz. She presented 14 watercolour paintings and pastels of flower pieces, which she donated to the association afterwards. They were all reproduced as etchings. ${ }^{60}$ Both, the original ones and the graphic reproductions, are today considered to be lost.

51 Participation with a still life, Illustrierter Katalog der III. Internationalen Kunstausstellun (Münchener Jubiläumsausstellung) im Königl. Glaspalaste zu München 1888 (München: Verlagsanstalt für Kunst und Wissenschaft, 1888), 9, No. 609.

52 Red Anemones, Illustrierter Katalog der Münchener Jahresausstellung von Kunstwerken Aller Nationen im königl. Glaspalaste 1889 (München: Bruckmannsche Buchdruckerei, 1889), 10, No. 77.

53 Yellow Roses, Illustrierter Katalog der Münchener Jahresausstellung von Kunstwerken Aller Nationen im königl. Glaspalaste 1890 (München: Franz Hanfstaengl, 1890) 4, No. 97b.

54 Participation with two paintings, Flowers and Beans, Illustrierter Katalog der Münchener Jahresausstellung von Kunstwerken Aller Nationen im kgl. Glaspalaste 1891 (München: Franz Hanfstaengl, 1891), 8, No. 106a, b.

55 Still Life of Fruit, Illustrirter Katalog der Münchener Jahresausstellung von Kunstwerken aller Nationen im Kgl. Glaspalaste 1893 (München: Franz Hanfstaengl, 1893), 6, №. 100.

56 Pomegranates, Illustrirter Katalog der Münchener Jahresausstellung von Kunstwerken Aller Nationen im Kgl. Glaspalaste 1894 (München: Franz Hanfstaengl, 1894), 3, No. 64.

57 Participation with three paintings: Peonies, Peaches and Grapes and Plums, Große Berliner Kunstausstellung. Katalog. Berlin 1897 (Berlin: Rudolf Schuster, 1897), 8; Gutgesell, Alexandr von Berckholtz. Malerin und Mäzenin im 19. Jahrhundert, 43.

58 Die Sammlung der Markgrafen und Großherzöge von Baden im Schloss Baden-Baden 5. bis 21. Oktober 1995, (Baden-Baden: Sotheby's Holdings, 1995), 104, No. 4305; oil on paper, $33.5 \times 23.5 \mathrm{~cm}$, signed and dated on lower left $A$. v. Berckholtz 1895

59 Oil on wood, $73.5 \times 55.5 \mathrm{~cm}$, signed and dated on lower right A. v. Berckholtz 1888.; oil on wood, $43.5 \times 30.5 \mathrm{~cm}$, Signed and dated on lower left $A$. v. Berckholtz 1893 . Gutgesell, Alexandra von Berckholtz. Malerin und Mäzenin im 19. Jahrhundert, 43, 246-247, 250-251, o. 26.

60 Düna-Zeitung, 123 (5th June 1899); Boetticher, Malerwerke des 19. Jahrhunderts, 84; Gutgesell, Alexandra von Berckholtz. Malerin und Mäzenin im 19. Jahrhundert, 42. 


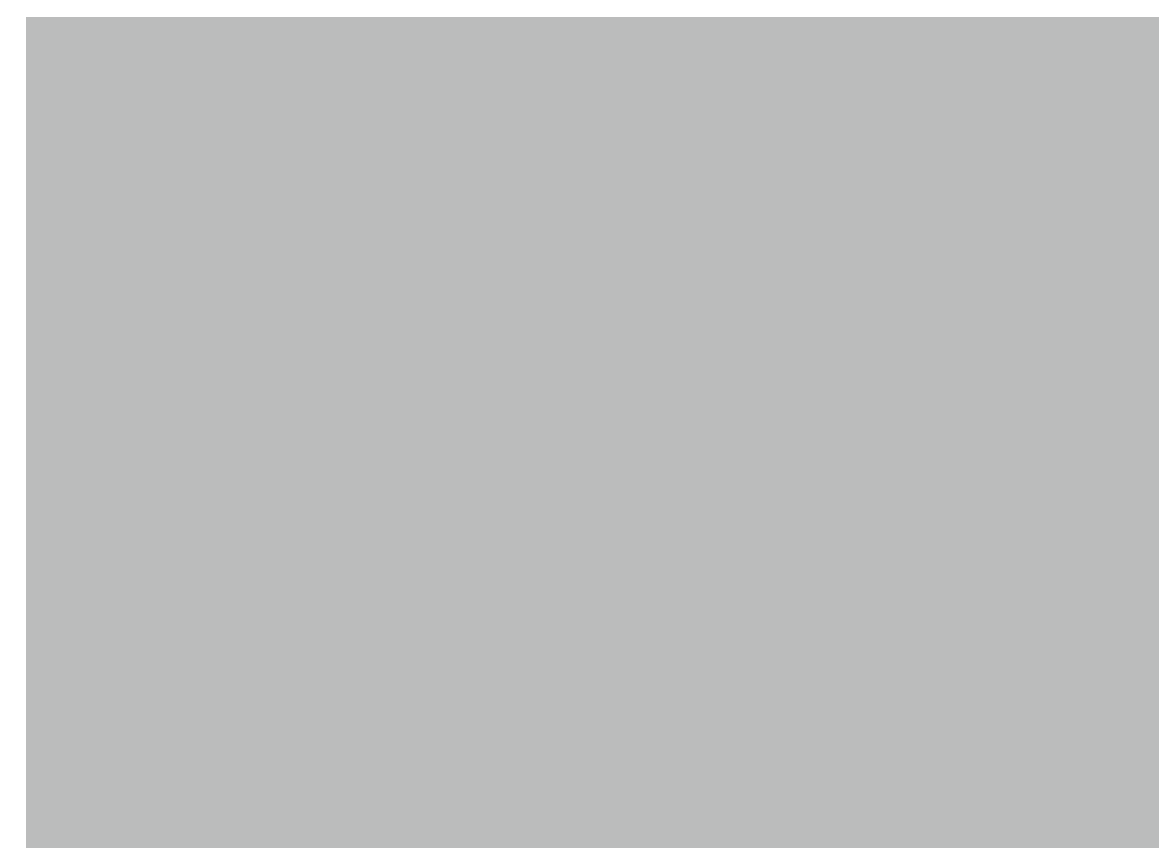

FIG. 18. ALEXANDRA VON BERCKHOLTZ. STILL LIFE OF ROSES. 1887, OIL ON CANVAS, $22.5 \times 31.5$ CM. PRIVATE COLLECTION.

\section{STILL LIFE PAINTINGS IN NICE}

From October 1876 until September 1877 Alexandra von Berckholtz stayed in Nice, Clarens and Luzern together with the Swiss still life painter Theresia Maria Hegg de Landerset (1829-1911). She influenced Alexandra in the floral still life genre, which was given special emphasis in her later work. Many depictions of different flowers and fruits were created by Alexandra von Berckholtz during that time, e.g. a watercolour painting of two roses seeming to float freely in open space, which reminds the spectator of the characteristic representation method of plants in herbaria of the Renaissance. ${ }^{61}$ After that stay in Nice Alexandra von Berckholtz focused her main

mphasis on the depiction of flowers in her oil paintings as well e.g. in apricot coloured roses lying on a stone wall or plate, which fill the entire space of the picture (Fig. 18). For most of her flower

FIG. 19. ALEXANDRA VON BERCKHOLTZ. BUNCH OF FLOWERS IN A VASE. 1864, WATERCOLOUR OVER PENCIL ON PAPER, $28.5 \times 22$ CM. PRIVATE COLLECTION, ALLHARD VON LOESCH, BAD HOMBURG. 
pieces, the Dutch and Flemish Baroque painters, e.g. Cornelis de Heem (1631-1695), served as models for her compositions and her colouring, but she did not examine the iconographic significance of all the different flowers and insects in order to convey a special meaning of the image.

The fact that Alexandra von Berckholtz had already paid attention to the genre of the still life prior to 1877 is demonstrated by a recently discovered watercolour painting over pencil on paper of a bunch of flowers in a vase (Fig. 19). Her engagement with this topic thirteen years earlier had also taken place in Nice, as the inscription at the lower edge states, "Nice 1864". Perhaps she had already met Theresia Maria Hegg de Landerset at that time? Their later contact is proven by a portrait of "Mme Teresa Hegg", drawn by Alexandra in her sketchbook on 28 September 1877 in Clarens. ${ }^{62}$

Alexandra herself supported the Austrian still life painter Ludwig Adam Kunz (1857-1929), who in 1876-1878 had studied at the Academy of Arts in Munich in Franz von Lenbach's class. In 1896, he was appointed professor at the academy. His natures mortes stylistically resemble Alexandra's works to a high degree, e.g. compare her abovementioned Floral Still Life with a Wine Glass with Kunz' Still Life with a Goblet and Fruit. Its composition is arranged in a similar way, including also the reflection of the light effect on the surface of the glass. ${ }^{63}$

\section{CONNECTIONS WITH THE BALTIC}

In Munich Alexandra von Berckholtz was actively involved in the art scene. She was a member of the Artists' Association of Munich since 1865, from 1866 the Artists' Benefit Society (KünstlerUnterstützungsverein) of Munich - to which she left 4,000 marks in her testament, and Allgemeine Deutsche Kunstgenossenschaft from 1890. She also liked to socialize with Baltic artists in Munich. One of them was the Russian lieutenant and marine painter Paul Baron von Tiesenhausen (1836-1876), who had been studying at the Academy

62 City Archives of Offenburg Inv.-No. 26/21/023; Gutgesell, Alexandra von Berckholtz. Malerin und Mäzenin im 19. Jahrhundert, 40, Picture 45.

63 Oil on wood, $65.5 \times 56.5 \mathrm{~cm}$, signed and dated upper right L. Adam Kunz 1913, private collection; Gutgesell, Alexandra von Berckholtz. Malerin und Mäzenin im 19. Jahrhundert, 246, Picture 288 . of Munich since 20 April 1864. Further information provided in the matriculation register states the social status of his parents as landowners in Estonia and his Lutheran confession. ${ }^{64}$ Alexandra painted the portrait of his wife Mary Jenken (died 1870), ${ }^{65}$ whom von Tiesenhausen married in 1867. He participated, alongside Alexandra von Berckholtz, in the First International Exhibition in Munich in 1869 with his oil painting Estonian Coast, which was acquired by the Artists' Association of Stuttgart. ${ }^{66}$ In 1877 he took part in an exhibition in Stuttgart at the gallery Herdtle $\mathcal{E}$ Peters with a seascape, ${ }^{67}$ two years earlier he had been bestowed honorary membership of the Academy of Art in St. Petersburg. His oil painting Pier in Turbulent Waters is part of the collection at Neue Pinakothek Munich. ${ }^{68}$

On 6 May 1880, Alexandra von Berckholtz donated a stained glass painting for the fifth window of the southern aisle of St. Peter's in her birthplace Riga. To that church her ancestors had already contributed liturgical devices and candelabra, which were located on a pillar next to the crypt of the Berckholtz family emblazoned with their coat-of-arms. Alexandra's pointed arch rectangular window was placed next to her forefathers' tomb. The depiction showed Christ on the cross. The three Marys - the three ladies at the grave - are standing on the left. John the Baptist is kneeling on the right at the foot of the cross with his arms wrapped around Christ's feet. Under a cloudy sky in the background the Roman centurion Longinus can be seen pointing at the cross with his left hand. Longinus pierced the side of the Lord with the lance - later to be known as the Holy Lance - and recognized Jesus as the Son of God. Below that scene the window included two smaller rectangular paintings. The left one depicted the family crest with the birch tree and the black grouse. The banner beneath represented the family's principles of steadfastness and diligence: "Constantia et Zelo." The picture on the right showed

64 Paul von Tiesenhausen, Matrikelbuch 1841-1884, matrikel.adbk.de/matrikel/mb_18411884/jahr_1864/matrikel-02051 (accessed 03.11.2018).

65 Abendblatt der Allgemeinen Zeitung, 76 (17 March 1899); Gutgesell, Alexandra von Berckholtz. Malerin und Mäzenin im 19. Jahrhundert, 141-142.

66 York Langenstein, Der Münchner Kunstverein im 19. Jahrhundert. Ein Beitrag zur Entwicklung des Kunstmarkts und des Ausstellungswesens (München: Kunstverein München, 1983), 47

67 Kunstchronik, 31 (9th May 1877), 499.

68 Oil on canvas, $19.5 \times 40 \mathrm{~cm}$, Inv.-No. 11803 


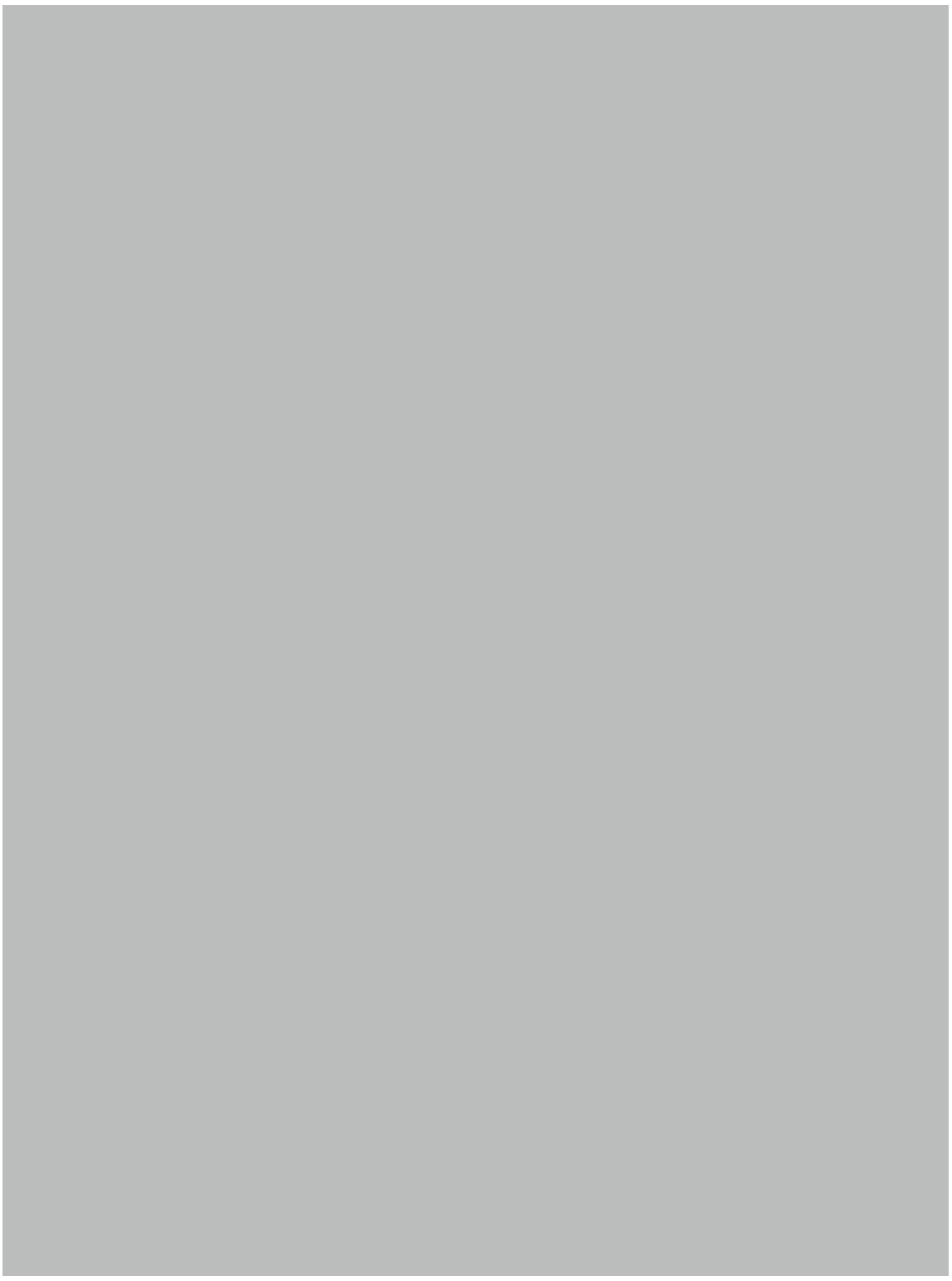

FIG. 20. ALEXANDRA VON BERCKHOLTZ. CHRIST ON THE CROSS (DETAIL). 1932 (1880), STAINED GLASS PAINTING, PHOTOGRAPHY, 6.7 × 4.5 CM. LATVIAN STATE HISTORICAL ARCHIVE, RIGA, INV.-NO. 773-15 KM. an angel dressed in a long gown and a cloak, sitting, holding with both hands a second banner with the donator's name "Gestiftet von Alexandra von Berckholtz München 1880" (Fig. 20). ${ }^{69}$

As a consequence of the press reports in Riga about her donation, ${ }^{70}$ Alexandra's cousin Conrad Ruecker (born 1817), chairman of the parish council of St. Peter's, had produced a photograph of the window which was exhibited at the Artists' Association of Riga. The painting had been manufactured by the Royal Bavarian glass factory of Franz Xaver Zettler (1841-1916) in Munich, which exported its goods to numerous European countries. Whether Alexandra von Berckholtz also painted the window by herself is unknown. St. Peter's was destroyed during the Second World War. Its windows burst in a grenade fire on 29 June 1941. In 1967, the reconstruction of the church began. Thirty years later it was included in the list of UNESCO's World Heritage of Humanity. Alexandra's window, however, is irretrievably lost.

\section{DRAWINGS OF UNKNOWN LADIES}

Alexandra was friends with Franz Xaver Zettler, who owned at least four of her drawings. This is evidenced by the catalogue of an auction at Emil Hirsch on 5 March 1921 in Munich. Zettler's private collection comprised 420 Bavarian, Dutch, Flemish, and French art works. Alexandra von Berckholtz' half-length portraits depicted a young lady (1842), Mathilde von Rottenhof (1852), another lady in a three-quarter profile (1853), and a man with a beard seen in a profile view (1859). ${ }^{71}$ Often her drawings served as models for oil paintings and cartons. Maybe the two cartons discovered in a private collection in Bad Homburg depicting two different ladies (Fig. 21 and 22) show one of the women mentioned above?

69 Gutgesell, Alexandra von Berckholtz. Malerin und Mäzenin im 19. Jahrhundert, 42, 424427 , No. 113A, B, C.

70 Rigasche Zeitung, 131 (7 June 1880).

1 Handzeichnungen alter und neuer Meister aus dem Nachlasse des Kommerzienrats F.X. Zettler in München, ehem. Hofglasmalereibesitzers, nebst anderen Beiträgen, ed. by Emil Hirsch (München: 1921), 5, No. 37-40; Portrait of a young lady, pencil on paper, $22.2 \times 27.6 \mathrm{~cm}$, signed and dated A. v. Berckholtz 1842; pencil on paper, $19.5 \times 24 \mathrm{~cm}$, signed and dated A. v. Berckholt 1852; pencil on paper with white and pink heightening, $18.7 \times 23.5 \mathrm{~cm}$, monogrammed and datec A. v. B. 1853; pencil and chalk on paper with white heightening, $17 \times 22 \mathrm{~cm}$, monogrammed an dated A v. B. 8. Oct. 1859; Gutgesell, Alexandra von Berckholtz. Malerin und Mäzenin im 19 Jahrhundert, 42, 49, 434 (No. 16), 435 (No. 43), 436 (No. 46, 58). 


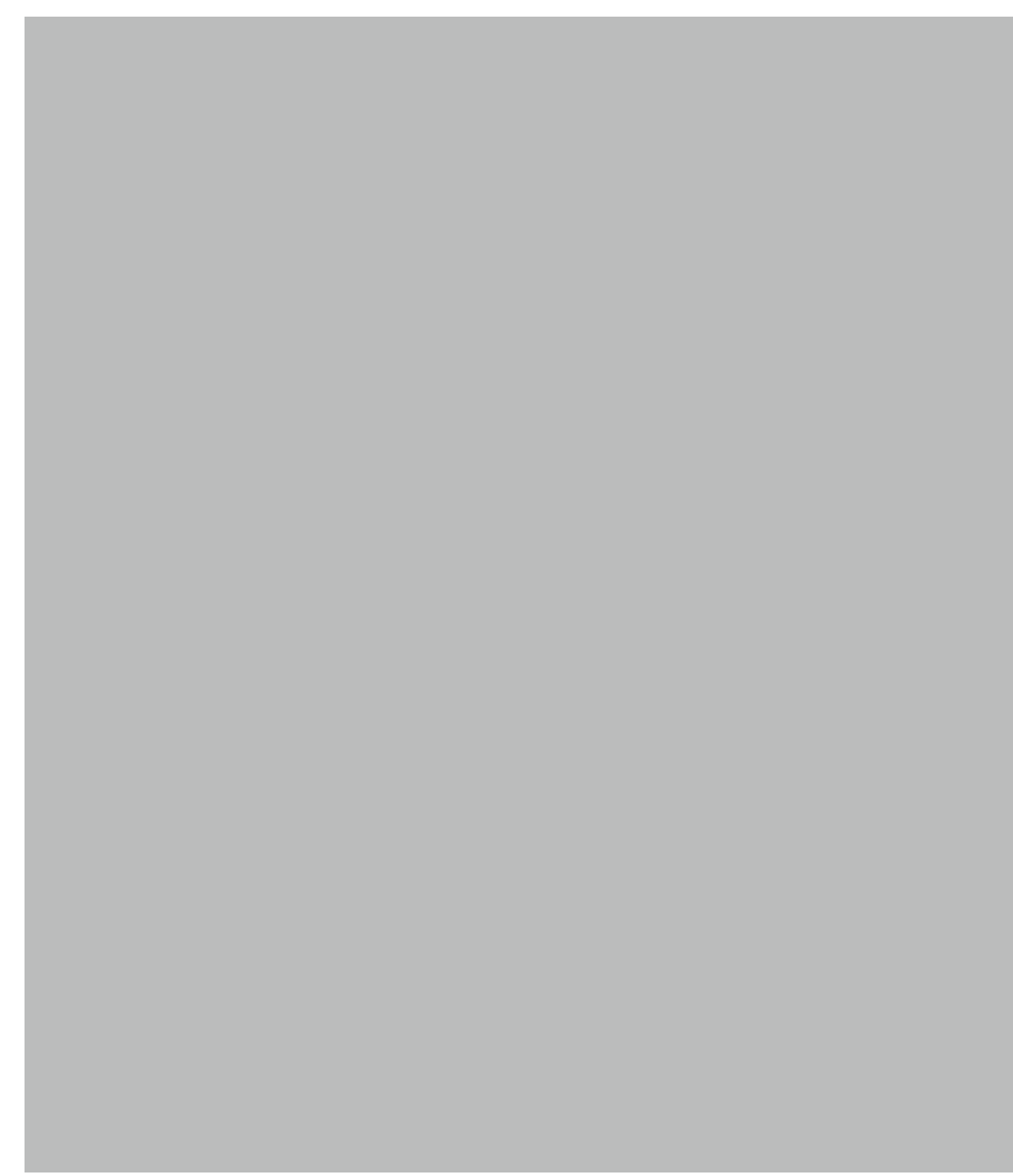

FIG. 21. ALEXANDRA VON BERCKHOLTZ. PORTRAIT OF AN UNKNOWN LADY. CHARCOAL ON CARDBOARD, $52.6 \times 42.4$ CM. PRIVATE COLLECTION, ALLHARD VON LOESCH, BAD HOMBURG

Perhaps the drawing of a lady in a private collection in the Netherlands (Fig. 23) is one of the persons in question? The portrait of the woman with the veil is part of an album formerly belonging to Alexandra's nephew Wilhelm Offensandt von Berckholtz, who was the executor of her last will.

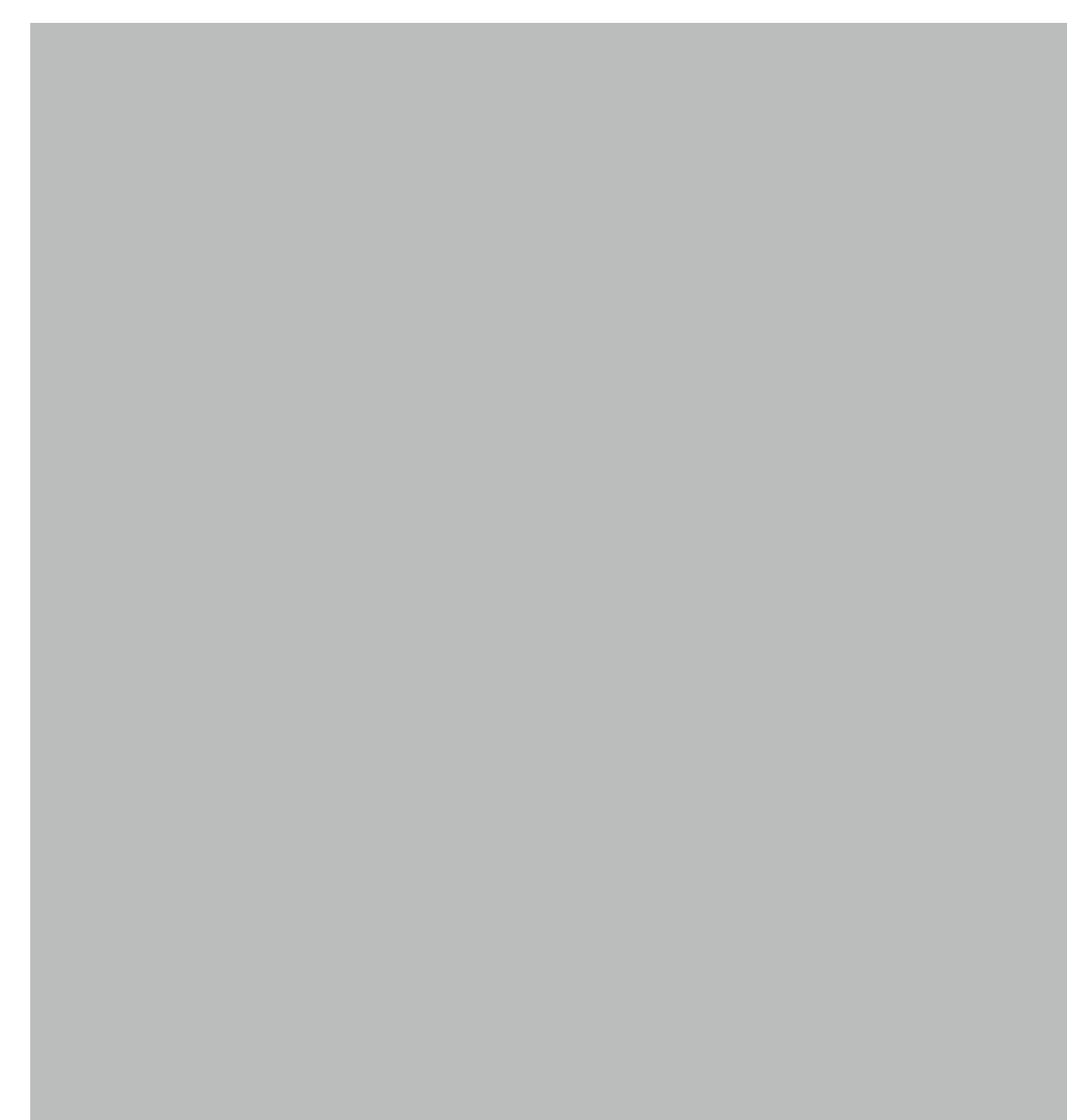

FIG. 22. ALEXANDRA VON BERCKHOLTZ. PORTRAIT OF AN UNKNOWN LADY. PENCIL ON PAPER, 43 × 39.6 CM. PRIVATE COLLECTION, ALLHARD VON LOESCH, BAD HOMBURG.

Alexandra von Berckholtz died on 16 March 1899 in Munich. In her testament she bequeathed a lot to her family members and friends, and donated the large amount of 18,000 marks for charitable purposes. E.g. the Women's Association (Frauenverein) of Karlsruhe received 2,000 marks, the Evangelical Children's Orphanage in Munich 2,000 marks, and the Artists' Benefit Society (Künstlerunterstützungsverein) 4,000 marks. In addition to that, her servants altogether received 21,000 marks. 


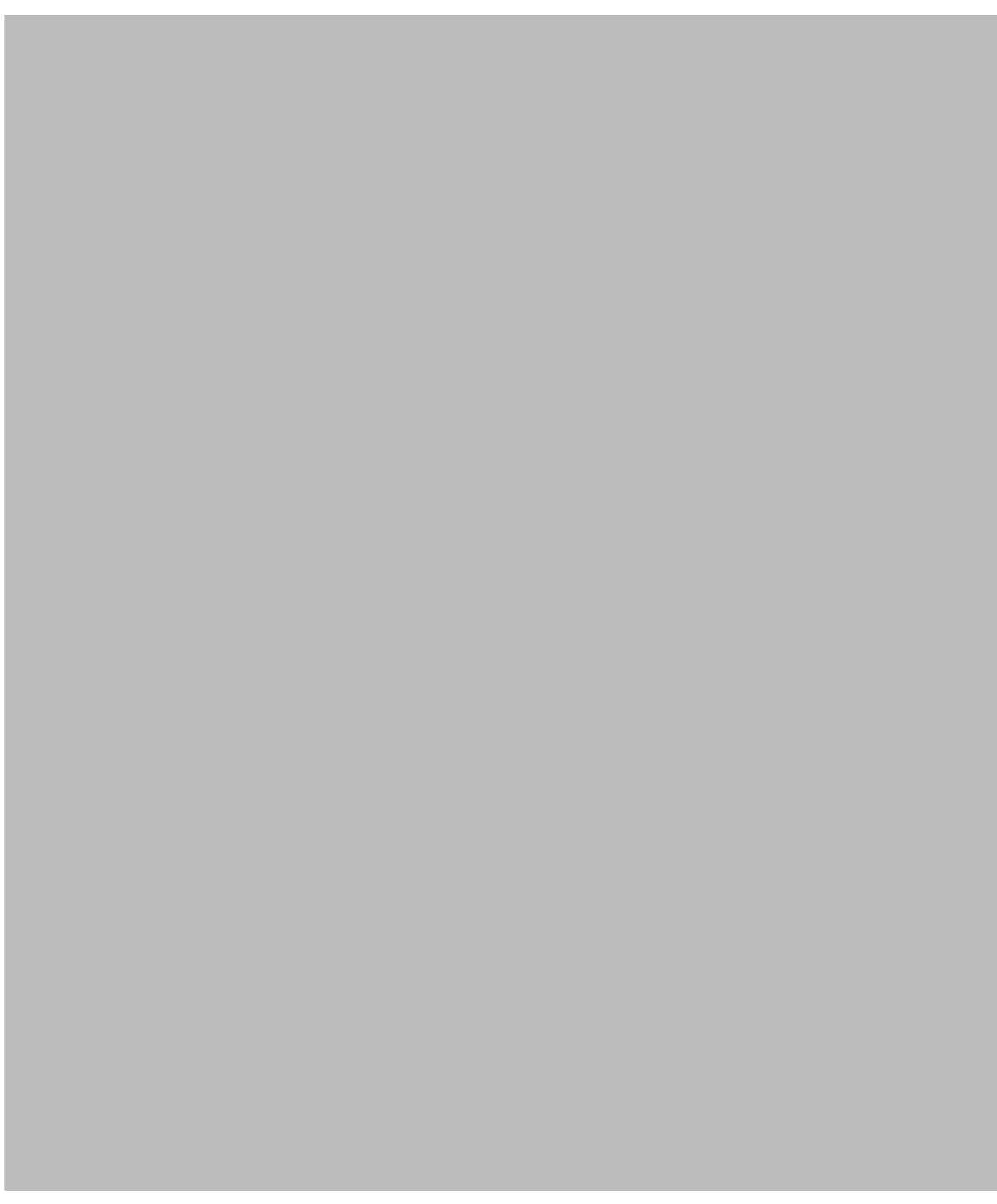

FIG. 23. ALEXANDRA VON BERCKHOLTZ. PORTRAIT OF AN UNKNOWN LADY. 1853, $31 \times 24$ CM. PRIVATE COLLECTION IN THE NETHERLANDS.

\section{WORKS AT THE ART MUSEUM OF ESTONIA}

The author would like to conclude with two significant paintings by Alexandra von Berckholtz at the Art Museum of Estonia in Tallinn. The first one presents the portrait of the county commissioner Carl Otto von Loewenstern (1755-1833) (Fig. 24) from Antsla in Livonia,

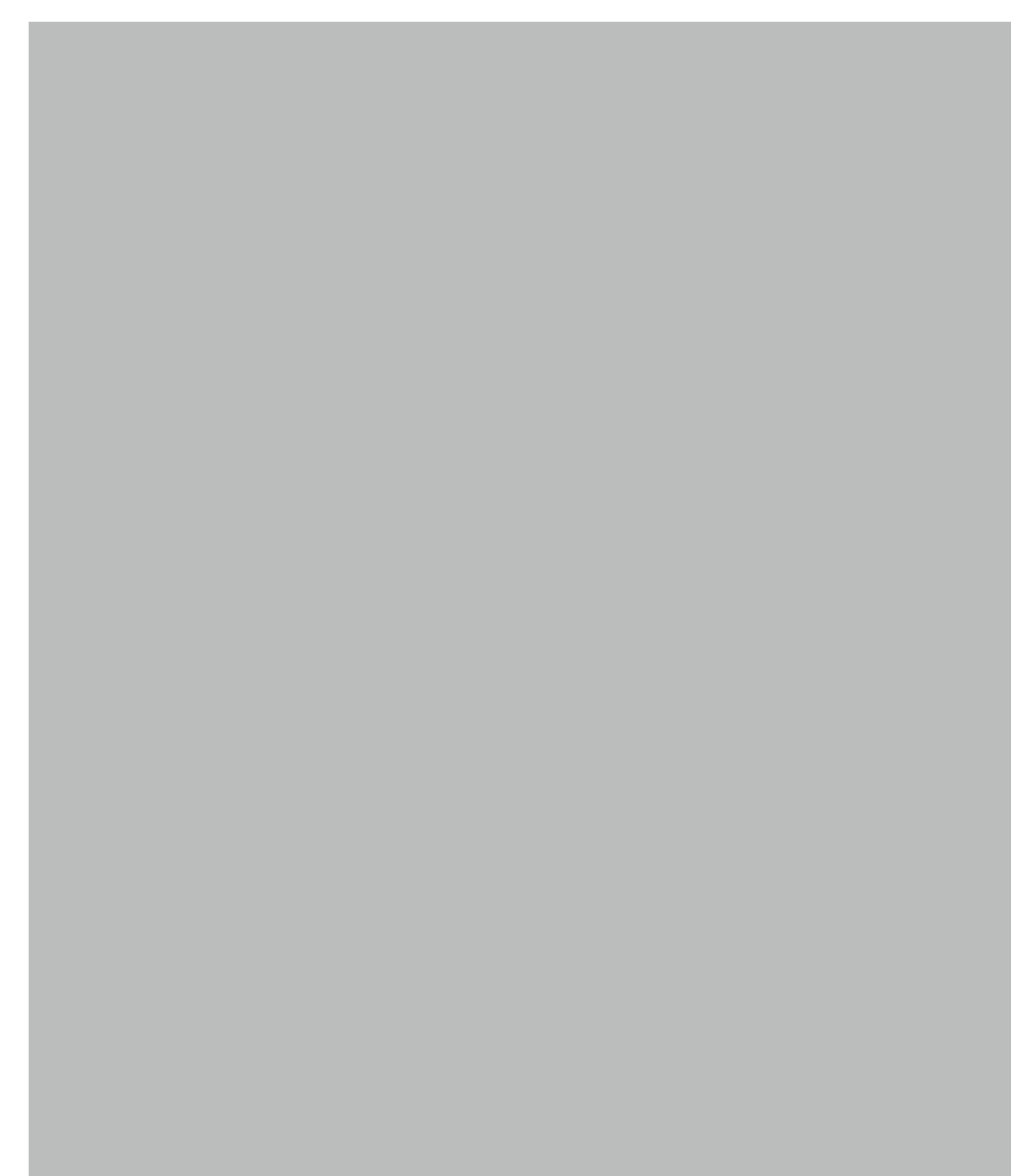
FIG. 24. ALEXANDRA VON BERCKHOLTZ (ATTRIBUTED). CARL OTTO VON LOEWENSTERN J 190:249 VM 146. THE ART MUSEUM OF ESTONEU TALUNN PHOTO: STANISLAV STEPAŠKO.

owner of a knight's estate. ${ }^{72} \mathrm{He}$ is presented in a half-length portrait in semi-profile. He is wearing a uniform; a coat is draped over his left shoulder. The portrait is attributed to Alexandra von Berckholtz,

72 Otto Magnus von Stackelberg, Genealogisches Handbuch der baltischen Ritterschaften Teil 2, 1.2: Estland (Görlitz: C. A. Starke, 1930), 120-126. 
but the reverse of the painting reveals additional information: "Gem. v. C. Edlinger." Therefore, it is not improbable that the portrait painter Carl Franz Edlinger (1785-1823) from Dresden could be the artist. ${ }^{73}$ From 1806 Baron von Loewenstern lived in Dresden, where he supported several artists. One of them was Carl Christian Vogel von Vogelstein (1788-1868), who became painter at the Russian court in 1808. Stylistically speaking, Alexandra von Berckholtz could be considered the artist of the portrait in question, too.

The second painting - which is signed and dated on the lower left "A. v. Berckholtz 1881." - is an exceptional still life (Fig. 25), to which no comparative examples have yet been found in Alexandra von Berckholtz' oeuvre. The composition is set on a kind of mantelpiece, covered by red-brown patterned brocade. Next to a white lace handkerchief in the middle with a yellowish rose on it, there is a black open jewellery box. A string of pearls and a golden ring lie in front of it. Opposite on the right, red flowers, maybe cloves, are placed next to a fan. Behind the objects, next to a holly on the left and a lace scarf draped on the right, a mirror in an oval golden frame reflects a painting hanging on the wall behind the viewer.

\section{FEMALE BALTIC ARTISTS}

Female Baltic artists are today still a general research desideratum. The book Baltische Maler und Bildhauer des XIX. Jahrhunderts (Baltic Painters and Sculptors of the 19th Century) by Wilhelm Neumann ${ }^{74}$ just mentions six women, whereas in his Lexikon Baltischer Künstler (Encyclopedia of Baltic Artists), ${ }^{75}$ published six years later, 46 female Baltic artists are named. In recent years, several studies have been carried out researching the lives and works of these women in detail, e.g. by Ms. Baiba Vanaga, who wrote her doctoral thesis on Women Artists in Latvia from the Middle of the 19th Century until 1915, ${ }^{76}$ by Ms. Christin Conrad, who curated an exhibition about the painter

73 Carl Clauß, "Edlinger, Karl Franz", Allgemeine Deutsche Biographie, 5 (1877), 648.

74 Wilhelm Neumann, Baltische Maler und Bildhauer des XIV. Jahrhunderts (Riga: Alexander Grosset 1902)

75 Wilhelm Neumann, Lexikon baltischer Künstler (Riga, 1908).

76 Baiba Vanaga, Sievietes mākslinieces Latvijā laikā no 19. Gadsimta vidus lìdz 1915. Gadam promocijas darba kopsavilkums Women artists in Latvia from the middle of the 19th centur. until 1915 (Rīga: Latvijas Mākslas Akadēmija, 2015).

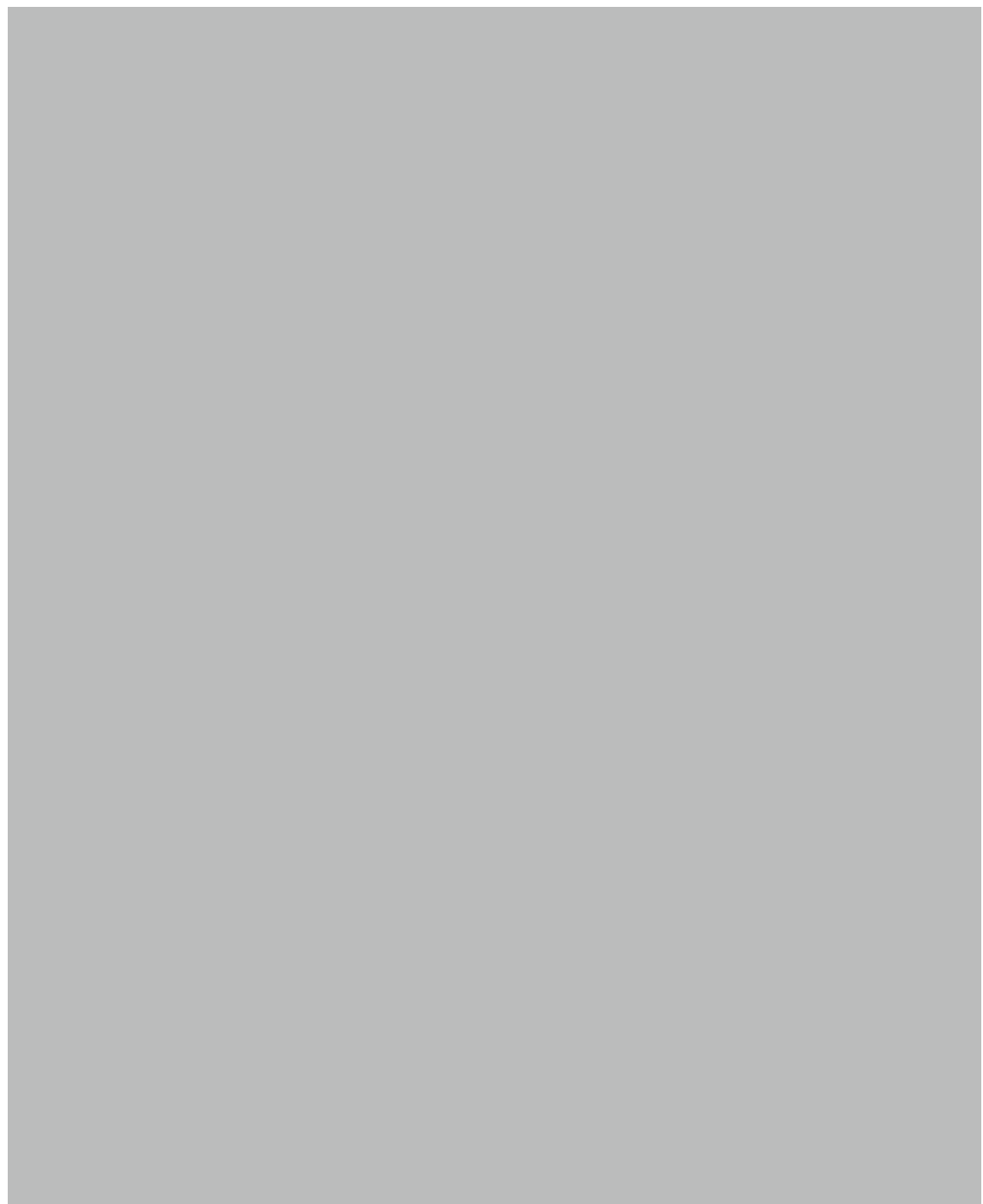

FIG. 25. ALEXANDRA VON BERCKHOLTZ. STILL LIFE. 1881, OIL ON CARDBOARD, $26.1 \times 21.8$ CM. THE ART MUSEUM OF ESTONIA, TALLINN, INV.-NO. EKM J 190:382 VM 161. THE ART MUSEUM OF ESTONIA TALLINN. PHOTO: STANISLAV STEPAŠKO. 
Julie Hagen-Schwarz at Kunstsammlungen und Museen Augsburg (Art Collections and Museums of Augburg) ${ }^{77}$ and who is working on a volume of selected letters by the artist, and by Ms. Kadi Polli with catalogues and exhibitions at the Art Museum of Estonia, such as The Modern Woman - New Identities in cooperation with the Ateneum Art Museum in Helsinki.

Many paintings, drawings, and sketchbooks by female Baltic artists are privately owned. They are still unknown and constitute a valuable source for research. Since the publication of the monograph on Alexandra von Berckholtz in May 2017, several of her other works have been discovered through private owners. The author would like to thank all private owners for the support they have given so far. ${ }^{78}$ Consequently, a second volume on the artist is intended to be published.
Natalie Gutgesell: The Baltic Portrait and Still Life Painter Alexandra von Berckholtz (1821-1899)

Keywords: Alexandra von Berckholtz; female Baltic artists; PORTRAIT; STILL LIFE; 19TH CENTURY

\section{SUMMARY}

The Baltic artist Alexandra von Berckholtz was among the most important portrait painters of her time. However, her works had disappeared from art-historical memory because, after her death, they were sold and spread all over the world. An international research project started in 2014 was able to rediscover her works and her life story.

Von Berckholtz was given her first art lessons in 1841 by the court painter Louis Wagner in Karlsruhe, Germany. From 1847 until 1854 she studied in Paris at the studio of the history painter Joseph-Nicolas Robert-Fleury, who had considerable influence on her pictorial style which combined realism and idealism. Another significant influence was Richard Lauchert, a former student and close friend of Franz Xaver Winterhalter. Von Berckholtz's numerous travels, e.g. to Switzerland, France, and the Czech Republic, were also a rich source of inspiration. She changed the conventions of nobility portrait and concentrated on still lifes in her later work, in which she reflected the Dutch style of the Baroque period. Alexandra von Berckholtz associated with important personalities from the fields of art, music, politics, and technology, and was socially active.

\section{CV}

Natalie Gutgesell (b. 1972): from 2005 to 2010 studied art history, theatre and media arts at the University of Erlangen-Nuremberg (M.A.); 2014 earned a PhD in art history with a thesis on the role of German Romantic poet Joseph Victor von Scheffel (1826-1886) as a visual artist. From 2014 to 2017, she led an international research project to research Alexandra von Berckholtz's artistic heritage in a number of public and private collections. She has curated exhibitions,
77 Exhibition catalogue: “Mut, liebe Julie!" Moritz Rugendas und die Malerin Julie HagenSchwarz, ed. by Christin Conrad, Christof Trepesch (Augsburg: Wißner-Verlag, 2016).

78 If other works are discovered in private collections, most of all in the Baltic States, the author would be delighted to receive information about them. 
for instance, in Karlsruhe and Weimar, lectured at conferences and universities, for instance, in Munich, Basel, Mainz, and Marburg, and published monographs and articles on 19th- and 20th-century art and culture. 
